\title{
Calcium efflux systems in stress signaling and adaptation in plants
}

\author{
Jayakumar Bose ${ }^{1}$, Igor I. Pottosin ${ }^{2}$, Stanislav S. Shabala ${ }^{3}$, Michael G. Palmgren $^{4}$ and Sergey Shabala ${ }^{1}$ * \\ 1 School of Agricultural Science, University of Tasmania, Hobart, TAS, Australia \\ ${ }^{2}$ Centro Universitario de Investigaciones Biomédicas, Universidad de Colima, Colima, México \\ ${ }^{3}$ School of Mathematics and Physics, University of Tasmania, Hobart, TAS, Australia \\ ${ }^{4}$ Department of Plant Biology, University of Copenhagen, Copenhagen, Denmark
}

Edited by:

Abraham D. Stroock, Cornell

University, USA

Reviewed by:

Jinkee Lee, Brown University, USA

Barbara G. Pickard, Washington

University in St. Louis, USA

*Correspondence:

Sergey Shabala, School of Agricultural Science, University of Tasmania,

Private Bag 54, Hobart, TAS 7001, Australia.

e-mail: sergey.shabala@utas.edu.au
Transient cytosolic calcium $\left(\left[\mathrm{Ca}^{2+}\right]_{\text {cyt }}\right)$ elevation is an ubiquitous denominator of the signaling network when plants are exposed to literally every known abiotic and biotic stress. These stress-induced $\left[\mathrm{Ca}^{2+}\right]_{\mathrm{cyt}}$ elevations vary in magnitude, frequency, and shape, depending on the severity of the stress as well the type of stress experienced. This creates a unique stress-specific calcium "signature" that is then decoded by signal transduction networks. While most published papers have been focused predominantly on the role of $\mathrm{Ca}^{2+}$ influx mechanisms to shaping $\left[\mathrm{Ca}^{2+}\right]_{\mathrm{cyt}}$ signatures, restoration of the basal $\left[\mathrm{Ca}^{2+}\right]_{\mathrm{cyt}}$ levels is impossible without both cytosolic $\mathrm{Ca}^{2+}$ buffering and efficient $\mathrm{Ca}^{2+}$ efflux mechanisms removing excess $\mathrm{Ca}^{2+}$ from cytosol, to reload $\mathrm{Ca}^{2+}$ stores and to terminate $\mathrm{Ca}^{2+}$ signaling. This is the topic of the current review. The molecular identity of two major types of $\mathrm{Ca}^{2+}$ efflux systems, $\mathrm{Ca}^{2+}$-ATPase pumps and $\mathrm{Ca}^{2+} / \mathrm{H}^{+}$exchangers, is described, and their regulatory modes are analyzed in detail. The spatial and temporal organization of calcium signaling networks is described, and the importance of existence of intracellular calcium microdomains is discussed. Experimental evidence for the role of $\mathrm{Ca}^{2+}$ efflux systems in plant responses to a range of abiotic and biotic factors is summarized. Contribution of $\mathrm{Ca}^{2+}$ ATPase pumps and $\mathrm{Ca}^{2+} / \mathrm{H}^{+}$exchangers in shaping $\left[\mathrm{Ca}^{2+}\right]_{\text {cyt }}$ signatures is then modeled by using a four-component model (plasma- and endo-membrane-based $\mathrm{Ca}^{2+}$-permeable channels and efflux systems) taking into account the cytosolic $\mathrm{Ca}^{2+}$ buffering. It is concluded that physiologically relevant variations in the activity of $\mathrm{Ca}^{2+}$-ATPase pumps and $\mathrm{Ca}^{2+} / \mathrm{H}^{+}$exchangers are sufficient to fully describe all the reported experimental evidence and determine the shape of $\left[\mathrm{Ca}^{2+}\right]_{\text {cyt }}$ signatures in response to environmental stimuli, emphasizing the crucial role these active efflux systems play in plant adaptive responses to environment.

Keywords: cytosolic calcium, signatures, oscillations, $\mathrm{Ca}^{2+}$-ATPase, calcium exchanger

\section{INTRODUCTION}

\section{CYTOSOLIC CALCIUM HOMEOSTASIS AND SIGNALING IN PLANT-ENVIRONMENTAL INTERACTION}

Calcium is an essential plant nutrient which plays a crucial structural role in cell walls and maintains membrane integrity. Calcium can easily interact with proteins, membranes, and organic acids through its ability to form different coordination bonds (from six to nine) which results in a high-affinity for carboxylate oxygen, rapid binding kinetics, and complex geometries (Medvedev, 2005; Case et al., 2007). Because of this, calcium can be a toxic cellular compound at higher concentrations as it would trigger aggregation of proteins and nucleic acids, precipitation of phosphates (present in ATP), and affect the integrity of lipid membranes (Case et al., 2007). As a result, plants have evolved efficient $\mathrm{Ca}^{2+}$ efflux mechanisms that can keep cytosolic free calcium, $\left[\mathrm{Ca}^{2+}\right]_{\mathrm{cyt}}$, at a constant and very low (submicromolar) level by exporting $\mathrm{Ca}^{2+}$ out of the cell or into the intracellular organelles (Dodd et al., 2010). In a typical plant cell, free $\mathrm{Ca}^{2+}$ concentrations are in the range of $1-10 \mathrm{mM}$ in the apoplasm, $100-200 \mathrm{nM}$ in the cytoplasm, $0.2-10 \mathrm{mM}$ in the vacuole, $\sim 1 \mathrm{mM}$ in the endoplasmic reticulum (reviewed in Medvedev, 2005), and 2-6 $\mu \mathrm{M}$ in chloroplast stroma (cf. Ettinger et al., 1999). Such extremely low $\left[\mathrm{Ca}^{2+}\right]_{\text {cyt }}$ creates a unique cellular environment in which $\left[\mathrm{Ca}^{2+}\right]_{\text {cyt }}$ concentration can be elevated by a factor of 10 or 20 rapidly (within seconds) upon sensing stress by using large electrochemical potentials either at the plasma or organelle membranes (Sanders et al., 1999). Indeed, $\left[\mathrm{Ca}^{2+}\right]_{\text {cyt }}$ elevation is an ubiquitous denominator of the signaling network when plants are exposed to soil acidity, salinity, anoxia, ozone, drought, osmotic, oxidative, heat and cold stresses, gaseous pollutants, mechanical cues, light, plant hormones, pathogens, bacterial, and fungal signals (reviewed in Sanders et al., 1999; McAinsh and Pittman, 2009). Resulting $\left[\mathrm{Ca}^{2+}\right]_{\text {cyt }}$ elevations are decoded by $\mathrm{Ca}^{2+}$ sensor proteins (e.g., CaM, CMLs, CDPKs, CBL/CIPKs) which regulate downstream targets leading to a stress-specific physiological response (DeFalco et al., 2010). 


\section{STRESS-SPECIFIC CALCIUM "SIGNATURES"}

Stress or stimuli induced $\left[\mathrm{Ca}^{2+}\right]_{\text {cyt }}$ elevations vary in magnitude, frequency, and shape. These depend on the severity of the stress as well the type of stress experienced, thus creating a unique stressspecific calcium "signature" that is then decoded by signal transduction networks. An example of such stress-specific "signatures" is shown in Figure 1, which depicts $\left[\mathrm{Ca}^{2+}\right]_{\text {cyt }}$ elevation in response to abscisic acid (ABA), anoxia, and salt stresses. Very often, not one but a series of repetitive spikes (oscillations) is observed in response to environmental stimuli (e.g., for $10 \mathrm{nM} \mathrm{ABA}$ in guard cells Figure 1A). In the case of anoxia, $\left[\mathrm{Ca}^{2+}\right]_{\mathrm{cyt}}$ elevation showed two distinctive peaks; one rapid (within a minute), and another one that lasted for hours (Figure 1B), whereas $\left[\mathrm{Ca}^{2+}\right]_{\text {cyt }}$ responses to salt stress did not have a second peak (Figure 1C).

The magnitude of $\left[\mathrm{Ca}^{2+}\right]_{\mathrm{cyt}}$ elevations shows a clear dosedependency of external stimulus as was shown for salinity (Tracy et al., 2008), ozone (Clayton et al., 1999), hypo-osmotic shock

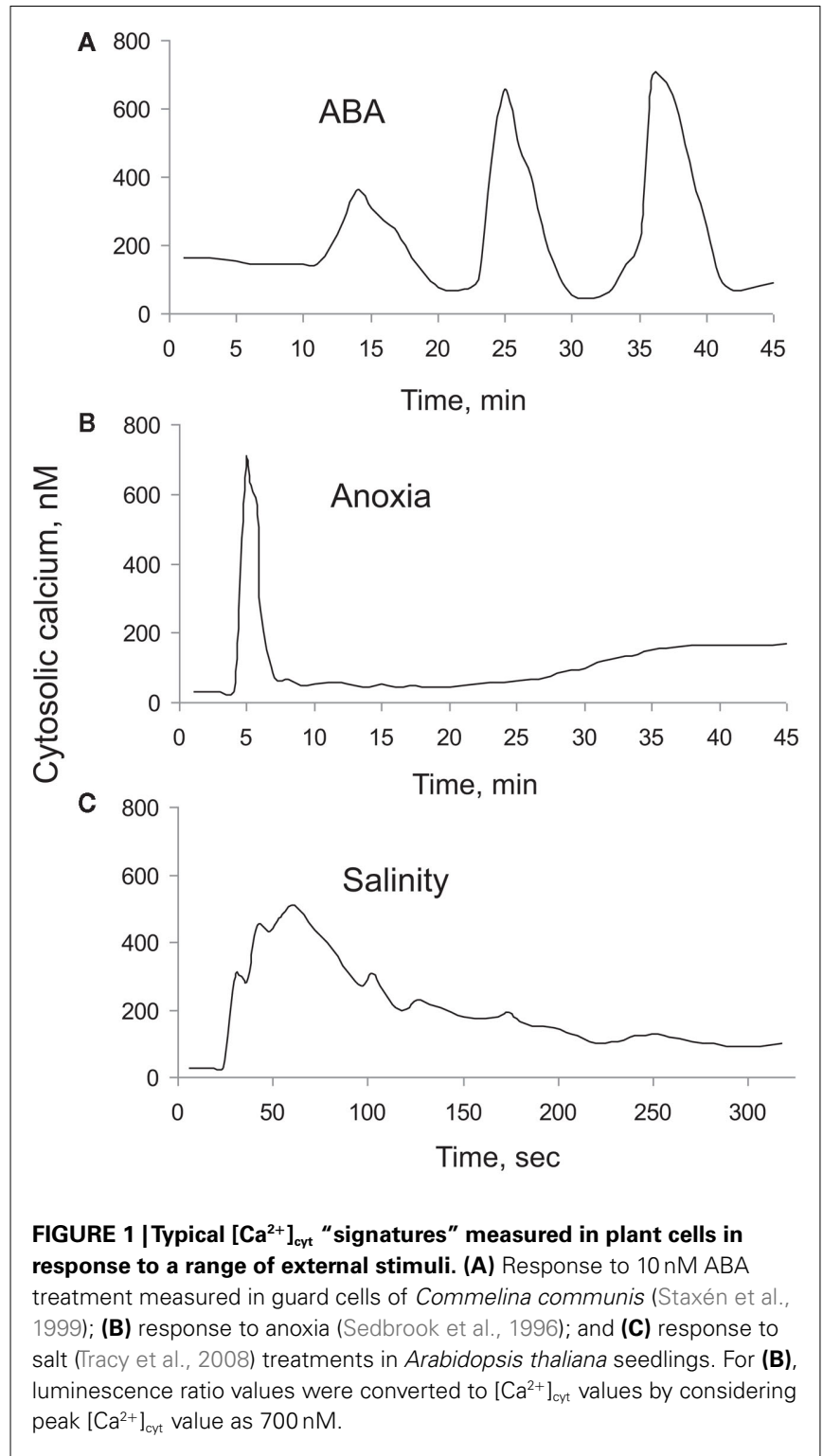

(Goddard et al., 2000), $\mathrm{H}_{2} \mathrm{O}_{2}$ (Price et al., 1994), high temperatures (Gong et al., 1998), and apoplastic $\mathrm{Ca}^{2+}$ treatments (McAinsh et al., 1995). In addition to the shape and magnitude of $\left[\mathrm{Ca}^{2+}\right]_{\mathrm{cyt}}$ elevation, repetition of $\left[\mathrm{Ca}^{2+}\right]_{\text {cyt }}$ elevations (spikes) could encode stimuli specific information. A classical example comes from Miwa et al. (2006) where Early Nodulation 11 (ENOD11) inductions were observed only when the $\left[\mathrm{Ca}^{2+}\right]_{\mathrm{cyt}}$ spikes lasted for at least $60 \mathrm{~min}$. Jasmonic acid treatment lengthened the period between spikes but did not alter the number of spikes required for ENOD11 expression, which suggests that indeed the number of spikes carries information required for ENOD11 expression (Miwa et al., 2006). More specific aspects of temporal encoding mechanisms and the role of cytosolic calcium oscillations in plant-environmental information are discussed in Section "Temporal Encoding Mechanisms: Cytosolic Calcium Oscillations." Altogether, these results demonstrate that information concerning the type and strength of stress are encoded within the magnitude, shape, and frequency of $\left[\mathrm{Ca}^{2+}\right]_{\text {cyt }}$ elevations. While most published papers have focused predominantly on the role of $\mathrm{Ca}^{2+}$ influx mechanisms in shaping $\left[\mathrm{Ca}^{2+}\right]_{\text {cyt }}$ signatures, the latter is impossible without involvement of $\mathrm{Ca}^{2+}$ efflux mechanisms, removing excess of $\mathrm{Ca}^{2+}$ from the cytosol. The purpose of the current review is to emphasize the role of $\mathrm{Ca}^{2+}$ efflux systems in the cytosolic $\mathrm{Ca}^{2+}$ signaling and shaping $\left[\mathrm{Ca}^{2+}\right]_{\text {cyt }}$ signatures.

\section{ENCODING ENVIRONMENTAL INFORMATION BY CALCIUM SPATIAL ENCODING: INTRACELLULAR CALCIUM MICRODOMAINS}

Pleiotropic $\mathrm{Ca}^{2+}$ effects on cellular functions are due to a spatiotemporal organization of $\mathrm{Ca}^{2+}$ signal, and it would be a gross oversimplification to assume that $\left[\mathrm{Ca}^{2+}\right]_{\mathrm{cyt}}$ is uniform across the cell. Instead, localized $\left[\mathrm{Ca}^{2+}\right]_{\text {cyt }}$ increases take place. Several factors make such localization possible. First, due to a presence of different buffer components in the cytosol $\mathrm{Ca}^{2+}$ mobility is very low (e.g., diffusion coefficient value of 1 to $5 \times 10^{-11} \mathrm{~m}^{2} / \mathrm{s}$ as compared to $8 \times 10^{-10} \mathrm{~m}^{2} / \mathrm{s}$ for pure water; Allbritton et al., 1992; Hille, 2001). The second contributing factor is a very specific configuration of different intracellular $\mathrm{Ca}^{2+}$ stores and their non-random distribution within a cell. Third, as a result of heterogeneous distribution and clustering of various $\mathrm{Ca}^{2+}$ transporters, the contact zones may exist between different organelles and a plasma membrane (PM), creating so-called " $\mathrm{Ca}^{2+}$ microdomains." Such microdomains may be only a few nanometers in size, as ones which occur at the immediate vicinity of an open $\mathrm{Ca}^{2+}$-permeable channel (Rizzuto and Pozzan, 2006).

There are numerous examples of a specific subcellular localization of a $\mathrm{Ca}^{2+}$ signal for a variety of plant responses, with a preferential involvement of the PM, vacuole, nucleus, mitochondria, chloroplasts, or some combinations of the aforementioned stores (Sanders et al., 1999). The shaping of $\mathrm{Ca}^{2+}$ response is very likely dependent on the non-random distribution of $\mathrm{Ca}^{2+}$ pumps, with the expression of ACA 2 in the ER, ACA 4 and 11 in the tonoplast, and ACA 8-10 in the PM (Sze et al., 2000; Harper, 2001; Boursiac and Harper, 2007; Kudla et al., 2010).

During polar growth, e.g., of root hairs or pollen tubes, $\mathrm{Ca}^{2+}$ increases occur exclusively in the apical zone, which can be explained by a localized expression of some $\mathrm{Ca}^{2+}$ influx components. CNGC18 encoding a putative $\mathrm{Ca}^{2+}$-permeable channel, 
whose expression is essential for tube growth, is predominantly expressed in the tip of a pollen tube (Frietsch et al., 2007), whereas $A C A 9 \mathrm{Ca}^{2+}$ pump is expressed uniformly over the tube (Schiøtt et al., 2004). Despite this uniform distribution, ACA 9 is believed to be active mainly in the high $\mathrm{Ca}^{2+}$ region in the tip, due to $\mathrm{Ca}^{2+}-\mathrm{CaM}$ binding; on the contrary, CNGC18 is presumed to be inactivated by $\mathrm{Ca}^{2+}-\mathrm{CaM}$ (Hepler and Winship, 2010). This pair could obviously form a $\mathrm{Ca}^{2+}$ oscillator, where $A C A 9 \mathrm{Ca}^{2+}$ pump may prevent long-lasting $\mathrm{Ca}^{2+}$ overloads. In addition, in the pollen tube the stimulation of a hyperpolarization-activated $\mathrm{Ca}^{2+}$-influx channel by external apoplastic CaM was demonstrated (Shang et al., 2005). This may add an additional feed-forward loop via $\mathrm{Ca}^{2+}$-activated exocytosis of CaM-containing vesicles (Hepler and Winship, 2010). Another $\mathrm{Ca}^{2+}$ influx channel, a stretch-activated one, was functionally characterized in patches derived from a tip of pollen tube (Dutta and Robinson, 2004), whose activity may be modulated by a periodic growth-related cell wall loosening.

Growth-related local $\mathrm{Ca}^{2+}$ rises are also mediated by PM ROSactivated channels (Foreman et al., 2003), and the activation of ROS-generating enzyme NADPH-oxidase by incoming $\mathrm{Ca}^{2+}$ tends to act as a positive feedback (Takeda et al., 2008). It is not surprising then that local $\mathrm{Ca}^{2+}$ and ROS changes are often coupled (Foreman et al., 2003; Terada, 2006; Cárdenas et al., 2008). Moreover, integration of NADPH-oxidase in sterol-rich lipid rafts in the tip of a pollen tube is very essential for generation of a tipfocused cytosolic $\mathrm{Ca}^{2+}$ gradient, underlying the polarized growth (Liu et al., 2009).

It is widely reported in animal literature that opening of a single $\mathrm{Ca}^{2+}$ permeable channel is capable of generating very high (up to $300 \mu \mathrm{M}$ ) local $\mathrm{Ca}^{2+}$ increases (Llinas et al., 1992; Naraghi and Neher, 1997; Heidelberger, 1998). The peak amplitude and spatial diffusion of the $\mathrm{Ca}^{2+}$ microdomain formed at the mouth of a $\mathrm{Ca}^{2+}$ channel and its immediate neighborhood depends on the conductance and $\mathrm{Ca}^{2+}$ selectivity of the channel, electrochemical gradient for $\mathrm{Ca}^{2+}$ across the membrane, and local intracellular $\mathrm{Ca}^{2+}$ buffering. To the best of our knowledge, no such work has been performed on plant systems.

Multiple roles have been attributed to such $\mathrm{Ca}^{2+}$ microdomains. Presynaptic termini $\mathrm{Ca}^{2+}$ microdomains are believed to control vesicles fusion and exocytosis (Llinas et al., 1992; Heidelberger et al., 1994). In non-excitable cells subplasma membrane $\mathrm{Ca}^{2+}$ microdomains control $\mathrm{Ca}^{2+}$-sensitive adenylate cyclases (Mons et al., 1998) and NO synthase (Lin et al., 2000). Strikingly, a very local $\mathrm{Ca}^{2+}$ increase at the mouth of an open PM channel may initiate the signaling sequence, leading eventually to gene activation far away (for a review see Rizzuto and Pozzan, 2006). Finally, $\mathrm{Ca}^{2+}$ channels themselves are targets for ultra-local $\mathrm{Ca}^{2+}$ signaling. Several types of $\mathrm{Ca}^{2+}$ channels such as L-type $\mathrm{Ca}^{2+}$-selective channels and CRAC have been shown to be inactivated by incoming $\mathrm{Ca}^{2+}$ (Zweifach and Lewis, 1995; Soldatov, 2003). Conversely, opening of several clustered RyR channels required a localized $\mathrm{Ca}^{2+}$ spark to be generated (Franzini-Armstrong and Protasi, 1997). Tight contact zones existing between the PM, ER, and mitochondria are not only important for creating local $\mathrm{Ca}^{2+}$ microdomains, but may result in direct transport of $\mathrm{Ca}^{2+}$ from a translocator in one membrane to its counterpart in another membrane, so-called "linked $\mathrm{Ca}^{2+}$ transport" (Poburko et al., 2004). As mitochondrial $\mathrm{Ca}^{2+}$ uptake may eventually lead to $\mathrm{Ca}^{2+}$ overload followed by the activation of the transition pore and release of apoptotic factors, location of mitochondria in relation of a high $\mathrm{Ca}^{2+}$ microdomain may be crucial for determining a cell's fate (Spät et al., 2009).

The physical basis for a non-random distribution of membrane elements is due to the existence of lipid rafts, well established for animal cells and becoming more evident also for plants (Zappel and Panstruga, 2008). In animal cells, recruitment of $\mathrm{Ca}^{2+}$ channels, pumps, exchangers into lipids rafts, and their functional consequences are known (Balijepalli and Kamp, 2008). In plants such evidence so far exists only for KAT1 channels (Sutter et al., 2006; Homann et al., 2007), but there is no reason to exclude such possibility also for plant $\mathrm{Ca}^{2+}$ permeable channels. Recently, we obtained some indirect evidence that double-pore $\mathrm{Ca}^{2+}$ (TPC) channels tend to cluster and communicate via local $\mathrm{Ca}^{2+}$ changes, as closed-open transitions of individual channels demonstrated interdependency (Pottosin, unpublished). Such an arrangement seems logical in light of a very high threshold for the TPC channel activation by intracellular $\mathrm{Ca}^{2+}$ (several tens of micromolar for the physiological voltage range (Schulz-Lessdorf and Hedrich, 1995; Pottosin et al., 1997; Pérez et al., 2008). Such high free $\mathrm{Ca}^{2+}$ concentrations occur only in close proximity of the mouth of an open $\mathrm{Ca}^{2+}$-permeable channel. A high threshold protects the cell from a global $\mathrm{Ca}^{2+}$ release from the non-exhaustible store, the central vacuole, which would be fatal. This consideration was obviously overlooked the when original hypothesis for the $\mathrm{Ca}^{2+}$-induced $\mathrm{Ca}^{2+}$ release based on the $\mathrm{Ca}^{2+}$ activation and $\mathrm{Ca}^{2+}$ permeability of vacuolar TPC was formulated (Ward and Schroeder, 1994). Recent studies with tpc-mutants show that TPC channels do not significantly contribute to any type of global $\mathrm{Ca}^{2+}$ response in plants (Ranf et al., 2008). On the other hand, clustering of the tonoplast TPC channels and/or their contacts with $\mathrm{PM} \mathrm{Ca}{ }^{2+}$. permeable channels of other organelles and $\mathrm{PM}$ would tend to split the large vacuole into multiple local $\mathrm{Ca}^{2+}$ circuits, where local feed-forward-looped $\mathrm{Ca}^{2+}$ rises could take place (Pérez et al., 2008). The fact that the tonoplast $\mathrm{Ca}^{2+} / \mathrm{H}^{+}$(CAX) exchanger also has a relatively low $\left(K_{\mathrm{d}} \sim 10-15 \mu \mathrm{M}\right)$ affinity for $\mathrm{Ca}^{2+}$ (Hirschi, 2001 ) indirectly indicates that it may encounter very high local $\mathrm{Ca}^{2+}$ rises.

\section{TEMPORAL ENCODING MECHANISMS: CYTOSOLIC CALCIUM OSCILLATIONS \\ Advantages of oscillatory strategy}

most other biological systems, cellular metabolism in general, and membrane transporters in particular, are governed by non-liner mechanisms and include a large number of positive and negative feedback loops (Hansen, 1978; Feijo et al., 2001; Shabala et al., 2006). It is not surprising, therefore, that such systems exhibit oscillatory behavior. Moreover, transient oscillatory responses are the most typical response of every feedback-controlled system to step-wise changes in external parameters. It is hardly surprising, therefore, that $\left[\mathrm{Ca}^{2+}\right]_{\text {cyt }}$ oscillations are widely reported in a range of plant systems (see below). Such a periodic behavior confers several functional advantages for the organism (Rapp, 1987), with precision of control and discrimination of true signals from environmental noise being the most important. Theoretical findings by 
Rapp et al. (1981) suggest that many biological oscillations reflect the biochemical implementation of analog-digital-analog control strategy; a strategy that provides significant functional advantages for living cells.

Oscillations may also facilitate synchronization of events widely separated in space between subcellular compartments (Lloyd and Stupfel, 1991), and it has been suggested that $\mathrm{Ca}^{2+}$ oscillations can act as cellular timekeepers to coordinate related biochemical reactions and enhance their overall efficiency (Izu and Spangler, 1993). Another advantage of oscillatory strategy is that oscillations may enhance signal efficiency specifically at low levels of stimulation. Experiments carried out on lymphocytes T cells revealed that oscillations in cytosolic free $\mathrm{Ca}^{2+}$ increase the efficiency and specificity of gene expression (Dolmetsch et al., 1998). The authors showed that this effect arises from the highly non-linear dependence of transcription on $\left[\mathrm{Ca}^{2+}\right]_{c y t}$, so that oscillations periodically exceed the threshold for activation whereas a small constant $\left[\mathrm{Ca}^{2+}\right]_{\mathrm{cyt}}$ rise of the same average magnitude does not. In other words, oscillatory control optimized sensitivity to weak external stimuli.

Theoretical studies also show that such systems will possess complex dynamics leading to "strange" behavior such as bifurcation and chaos (May, 1989), and both theoretical (Rand et al., 1981) and experimental (Shabala et al., 1997) evidence for the chaotic stomatal behavior were presented. Given the fact that the stomata aperture is controlled by $\left[\mathrm{Ca}^{2+}\right]_{\text {cyt }}$ modulation, evidence for deterministic chaos in $\left[\mathrm{Ca}^{2+}\right]_{\text {cyt }}$ kinetics is waiting to be revealed.

\section{$\mathrm{Ca}^{2+}$ oscillations in plant cells}

Two major types of $\left[\mathrm{Ca}^{2+}\right]_{\text {cyt }}$ oscillations are known: (i) a baseline spiking, in which the magnitude of the spike remains the same but the frequency of the spiking is affected by environmental stimulus, and (ii) sinusoidal $\left[\mathrm{Ca}^{2+}\right]_{\text {cyt }}$ oscillations, in which agonist dose regulates the amplitude but has no effect on oscillation frequency. In technical terms this is equivalent to the frequency and amplitude modulation (Berridge, 1997).

Over the last decade, calcium oscillations have been a popular subject of numerous reviews (e.g., McAinsh and Hetherington, 1998; Ng and McAinsh, 2003; McAinsh and Pittman, 2009; Roelfsema and Hedrich, 2010) and, thus, are only briefly covered here. Such oscillations have been found in various plant systems such as guard cells (McAinsh et al., 1995, 1997), pollen tubes (HoldawayClarke et al., 1997; Feijo et al., 2001), roots (Kiegle et al., 2000), root hairs (Ehrhardt et al., 1996; Monshausen et al., 2008), and some other systems (Bauer et al., 1998; Schonknecht et al., 1998). Oscillations in $\left[\mathrm{Ca}^{2+}\right]_{\text {cyt }}$ result from a dynamic balance of fluxes of $\mathrm{Ca}^{2+}$ into and out of the cytosol and include release and uptake from both intracellular stores and external media ( $\mathrm{Ng}$ and McAinsh, 2003). The frequency of $\left[\mathrm{Ca}^{2+}\right]_{\text {cyt }}$ oscillations ranges typically from ca $20 \mathrm{~s}$ (Bauer et al., 1998) to 10-15 min (McAinsh et al., 1995) and shows a clear dependence on the magnitude of external stimulus (discussed in the next section). The latter findings lead to the concept of the existence of a frequency encoding mechanism, which conveys information about the severity of environmental fluctuation (e.g., temperature; heavy metal toxicity; hormonal level) by means of $\left[\mathrm{Ca}^{2+}\right]_{\text {cyt }}$ spikes. The functional role of $\left[\mathrm{Ca}^{2+}\right]_{\text {cyt }}$ oscillations was shown in nodulation experiments with alfalfa. The pronounced $\left[\mathrm{Ca}^{2+}\right]_{\text {cyt }}$ spikes were observed only in nodulating wild type plants, but not in non-nodulating alfalfa mutant (Ehrhardt et al., 1996); they were also absent in roots of tomato plants which are not capable of nodulating.

Both plasma and endomembrane $\mathrm{Ca}^{2+}$ channels are considered to be essential for generation of stimulus-induced $\left[\mathrm{Ca}^{2+}\right]_{\text {cyt }}$ oscillations (McAinsh et al., 1995, 1997). Involvement of hyperpolarization-dependent $\mathrm{PM} \mathrm{Ca}{ }^{2+}$ channels (HACC) has been shown (Pei et al., 2000), and oscillatory coupling between MP and $\left[\mathrm{Ca}^{2+}\right]_{\text {cyt }}$ has been suggested (Grabov and Blatt, 1998; Blatt, 1999). Indirect control via ABA-induced $\mathrm{H}_{2} \mathrm{O}_{2}$ production and a subsequent activation of $\mathrm{Ca}^{2+}$ influx through HACC has also been demonstrated (Pei et al., 2000).

Repetitive transient $\left[\mathrm{Ca}^{2+}\right]_{\text {cyt }}$ spikes were observed in unicellular green alga Eremosphaera viridis upon stimulation with $\mathrm{Sr}^{2+}$ (Bauer et al., 1998). These spikes were inhibited in cells pretreated with either ruthenium red or ryanodine, two known agents affecting activity of ryanodine/cyclic ADP-ribose type of $\mathrm{Ca}^{2+}$ channel, indicating the involvement of ER channels in generation of $\left[\mathrm{Ca}^{2+}\right]_{\text {cyt }}$ oscillations. InsP $\mathrm{P}_{3}$-gated $\mathrm{Ca}^{2+}$-release channels have also been implicated (McAinsh and Hetherington, 1998). It was suggested that these channels may form a part of the signal transduction pathway of different stimuli based on difference in distribution, gating properties, and sensitivity.

\section{$\mathrm{Ca}^{2+}$ as a component of encoding/decoding mechanism}

Increases in $\left[\mathrm{Ca}^{2+}\right]_{\text {cyt }}$ have been observed in several cell types in response to a number of stimuli (see Stress-Specific Calcium "Signatures"). Most of these treatments resulted in long-lasting $\left[\mathrm{Ca}^{2+}\right]_{\text {cyt }}$ oscillations and showed all signs of frequency encoding. As such, a strong correlation between mechanical signal strength and an amplitude of the resulting $\left[\mathrm{Ca}^{2+}\right]_{\text {cyt }}$ spike has been shown in Nicotiana cotyledons (Knight et al., 1991, 1992). $\mathrm{Sr}^{2+}$-induced $\left[\mathrm{Ca}^{2+}\right]_{\text {cyt }}$ oscillations in Eremosphaera showed an increase in frequency and decrease in amplitude at increasing agonist concentrations (Bauer et al., 1998). In stomata guard cells, the period of $\left[\mathrm{Ca}^{2+}\right]_{\text {cyt }}$ oscillations increased from $T=8.3-13.6 \mathrm{~min}$ as external $\mathrm{Ca}^{2+}$ rose from 0.1 to $1.0 \mathrm{mM}$ (McAinsh et al., 1995). This is consistent with animal models (Tang and Othmer, 1995) and points out that the signal specificity may be encoded by the amplitude and frequency of oscillations.

At the other end of the equation is a decoding mechanism. It was suggested that the $\mathrm{Ca}^{2+}$ signature may be decoded by the differential effects of $\mathrm{Ca}^{2+}$ on various downstream $\mathrm{Ca}^{2+}$-regulated proteins, such as calmodulin, phosphoinositide-specific phospholipase $\mathrm{C}$, and $\mathrm{Ca}^{2+}$-dependent phosphatases and kinases (Tang and Othmer, 1995; Leckie et al., 1998; McAinsh and Hetherington, 1998). Direct evidence that calmodulin-dependent protein kinase II can decode the frequency of $\left[\mathrm{Ca}^{2+}\right]_{c y t}$ spikes into distinct amounts of kinase activity was given by De Koninck and Schulman (1998).

Dolmetsch et al. (1997) demonstrated that differential gene transcription in $\mathrm{B}$ lymphocytes is achieved through amplitude modulation of the $\left[\mathrm{Ca}^{2+}\right]_{\text {cyt }}$ signaling system. Low $\left[\mathrm{Ca}^{2+}\right]_{\text {cyt }}$ concentrations activate the nuclear factor of activated $\mathrm{T}$ cells (NF-AT), whereas much larger elevations stimulate a different set of transcriptional regulators. In their model, mechanisms of AM-modulation are based on the recruitment of a variable number of elementary events, resulting from the opening of either 
individual or small group of channels located in the internal stores (organized as a hierarchy). The same group has also shown that $\left[\mathrm{Ca}^{2+}\right]_{\text {cyt }}$ oscillation frequency can discriminate among different transcriptional pathways (Dolmetsch et al., 1998). While low frequency spikes recruited NF-kB alone, higher frequency oscillations $(T<6 \mathrm{~min})$ activated NF-AT, Oct/OAP, and NF-kB, resulting in a differential gene expression. Another work used caged $\mathrm{InsP}_{3}$ to induce forced $\left[\mathrm{Ca}^{2+}\right]_{\text {cyt }}$ oscillations in $T$ lymphocytes ( $\mathrm{Li}$ et al., 1998). It was shown that $\left[\mathrm{Ca}^{2+}\right]_{\mathrm{cyt}}$ oscillations were more effective in activation of the NF-AT gene expression than a single, prolonged $\left[\mathrm{Ca}^{2+}\right]_{\text {cyt }}$ increase, provided that the period was roughly $1 \mathrm{~min}$; slower $(T=2 \mathrm{~min})$ and faster $(T=0.5 \mathrm{~min})$ oscillations were less efficient (Li et al., 1998).

It was also shown in animal systems that $\left[\mathrm{Ca}^{2+}\right]_{\mathrm{cyt}}$ oscillations were more effective in $\mathrm{Ca}^{2+}$-sensitive mitochondrial dehydrogenase $(\mathrm{CSMDH})$ activation than a sustained $\left[\mathrm{Ca}^{2+}\right]_{\text {cyt }}$ increase of similar amplitude (Hajnoczky et al., 1995). In this work, sustained NADPH elevation was achieved when the $\left[\mathrm{Ca}^{2+}\right]_{\text {cyt }}$ oscillation frequency was $0.5-1 / \mathrm{min}$, while sustained increase in $\left[\mathrm{Ca}^{2+}\right]_{\text {cyt }}$ caused only a transient elevation of NADPH. These results suggest that the pulsating organization and frequency modulation of $\left[\mathrm{Ca}^{2+}\right]_{\text {cyt }}$ signaling are superior to amplitude modulation of $\left[\mathrm{Ca}^{2+}\right]_{\text {cyt }}$ responses in controlling mitochondrial metabolism. Thus, it appears that mitochondria are tuned to the oscillating $\left[\mathrm{Ca}^{2+}\right]_{\text {cyt }}$ signal.

\section{SHAPING CYTOSOLIC CALCIUM SIGNALS}

As prolonged $\left[\mathrm{Ca}^{2+}\right]_{\text {cyt }}$ elevation is detrimental to normal cell metabolism, the basal $\left[\mathrm{Ca}^{2+}\right]_{\text {cyt }}$ levels must be restored after the signaling process has been completed. This may be achieved by orchestrated action of the cytosolic buffering system, and by the action of $\mathrm{Ca}^{2+}$ efflux mechanisms present in the PM and endomembranes. As argued below, the buffering capacity of $\mathrm{Ca}^{2+}$ binding proteins inside the cytosol is rather limited, making the $\mathrm{Ca}^{2+}$ efflux system absolutely essential in the above process of restoration of basal $\left[\mathrm{Ca}^{2+}\right]_{\text {cyt }}$ levels.

\section{CYTOSOLIC BUFFERING}

Intracellular $\mathrm{Ca}^{2+}$ buffering is an important determinant of the $\mathrm{Ca}^{2+}$ signal specificity, as both the magnitude and kinetics of $\mathrm{Ca}^{2+}$ signatures are critically dependent on $\mathrm{Ca}^{2+}$ buffering (Lew et al., 1984; Koopman et al., 2001). At the same time, there appears to be no correlation between cytosol buffering capacity and steadystate free $\mathrm{Ca}^{2+}$ level (Rizzuto and Pozzan, 2006). In animal cells cytosolic $\mathrm{Ca}^{2+}$ buffering may be described by a simple MichaelisMenten formalism, with apparent dissociation constant $\left(K_{\text {app }}\right)$ ranging from 0.4 to $0.7 \mu \mathrm{M}$ and maximal capacity $\left(B_{\max }\right)$ of $0.15-$ $0.3 \mathrm{mM}$. Assuming for simplicity one (high-affinity)-site binding, the total-to-free $\mathrm{Ca}^{2+}$ ratio in cytosol could be expressed as

$\mathrm{Ca}_{\text {(tot) }} / \mathrm{Ca}_{\text {free }}=1+B_{\text {max }} /\left(\mathrm{Ca}_{\text {free }}+K_{\text {app }}\right)$

Assuming basal $\left[\mathrm{Ca}^{2+}\right]_{\text {cyt }}$ levels $=0.1 \mu \mathrm{M}$, one may calculate that only one of $200-600 \mathrm{Ca}^{2+}$ ions in cytosol is free while all others are bound.

In plants, a very high (15-45 $\mathrm{mM})$ cytosolic buffering capacity for $\mathrm{Ca}^{2+}$ was estimated by some authors (Plieth et al., 1997). This estimate, however, included vacuolar $\mathrm{Ca}^{2+}$ sequestration, and, more importantly, was made under the assumption that $\mathrm{Ca}^{2+}$ and $\mathrm{H}^{+}$always bind to the same sites; the assumption was later challenged by other authors (Schönknecht and Bethmann, 1998). Thus, it is generally accepted that the cytosolic buffering capacity in plants is not different from their animal counterparts, and is in a range of $B_{\max }=0.2-0.5 \mathrm{mM}$ (Trewavas, 1999).

Cytosolic $\mathrm{Ca}^{2+}$-buffering is achieved mainly by $\mathrm{Ca}^{2+}$ binding proteins. Most of these proteins also act as $\mathrm{Ca}^{2+}$-sensors (Schwaller, 2009). Arabidopsis genome alone harbors 7 calmodulin (CaM) and 50 calmodulin-like genes (McCormack et al., 2005). The estimated CaM concentration in the cytosol is between 5 and $40 \mu \mathrm{M}$ (Zielinski, 1998). These and some other proteins contain at least one (and up to six) specific helix-loop-helix structural motifs termed as EF-hand, which can interact each with other and bind $\mathrm{Ca}^{2+}$ in a co-operative manner, resulting in a protein activation due to a relatively small $\mathrm{Ca}^{2+}$ change. Another large group of $\mathrm{Ca}^{2+}$ sensor proteins are calcineurin B-like proteins, bearing three EF hands (10 CBL genes in Arabidopsis, Luan et al., 2002) and $\mathrm{Ca}^{2+}$-dependents protein kinases (CDPKs) with four EF hands (34 genes for CDPK in Arabidopsis, Cheng et al., 2002b). In $\mathrm{Ca}^{2+}$ sensors $\mathrm{Ca}^{2+}$ binding within EF-hand results in a relatively large scale conformational change, more pronounced than in a few "pure" $\mathrm{Ca}^{2+}$ buffering proteins such as calbindin and parvalbumin in animal cells.

The affinity and co-operativity of $\mathrm{Ca}^{2+}$ binding could vary greatly in different EF-proteins, and there are at least two classes of binding sites: one highly selective for $\mathrm{Ca}^{2+}$ against $\mathrm{Mg}^{2+}$, and another with a lower and comparable affinity for $\mathrm{Ca}^{2+}$ and $\mathrm{Mg}^{2+}$ (Gifford et al., 2007). In plants, besides EF-hand proteins, there are several other cytosolic $\mathrm{Ca}^{2+}$ binding (and normally, also $\mathrm{Ca}^{2+}$. regulated) proteins like phospholipase $\mathrm{D}$ and annexins (White and Broadley, 2003; Tuteja and Mahajan, 2007). Other $\mathrm{Ca}^{2+}$-binding proteins have been recently discovered (Ide et al., 2007).

\section{CALCIUM EFFLUX SYSTEMS}

The most potent factor in shaping $\left[\mathrm{Ca}^{2+}\right]_{c y t}$ signatures is the activity of $\mathrm{Ca}^{2+}$ efflux systems. These are of utmost importance in both keeping $\left[\mathrm{Ca}^{2+}\right]_{\mathrm{cyt}}$ at submicromolar level and in replenishing $\mathrm{Ca}^{2+}$ stores after $\left[\mathrm{Ca}^{2+}\right]_{\text {cyt }}$ signaling is completed. There are two groups of $\mathrm{Ca}^{2+}$ efflux mechanisms, $\mathrm{Ca}^{2+}$-ATPases and $\mathrm{Ca}^{2+}$ exchangers (CAX), both of which operate at the PM and endomembranes (Figure 2). $\mathrm{Ca}^{2+}$-ATPases are high-affinity $\left(K_{\mathrm{m}}=0.1-2 \mu \mathrm{M}\right)$ but low-capacity transporters whereas $\mathrm{Ca}^{2+}$ exchangers are low-affinity $\left(K_{\mathrm{m}}=10-15 \mu \mathrm{M}\right)$ but high-capacity transporters. This suggest that (i) $\mathrm{Ca}^{2+}$-ATPases may be primarily involved in termination of $\left[\mathrm{Ca}^{2+}\right]_{\text {cyt }}$ signaling, whereas (ii) $\mathrm{Ca}^{2+}$ exchangers may be primarily involved in removal of $\left[\mathrm{Ca}^{2+}\right]_{\mathrm{cyt}}$ when $\left[\mathrm{Ca}^{2+}\right]_{\text {cyt }}$ elevations are higher than normal (Sze et al., 2000). As a result, both $\mathrm{Ca}^{2+}$-ATPases and CAX transporters contribute to shaping the $\left[\mathrm{Ca}^{2+}\right]_{\mathrm{cyt}}$ signal. $\mathrm{Ca}^{2+}$-efflux transport mechanisms originated early on in biological evolution, and there is significant sequence conservation of these transporters in all forms of life (McAinsh and Pittman, 2009). This has facilitated the work to reveal the molecular identity of these systems. Significant knowledge exists about $\mathrm{Ca}^{2+}$-ATPases and CAX transporters in terms of activation kinetics and regulation, expression pattern, cellular locations, and physiological functions (Sze et al., 2000; Pittman 


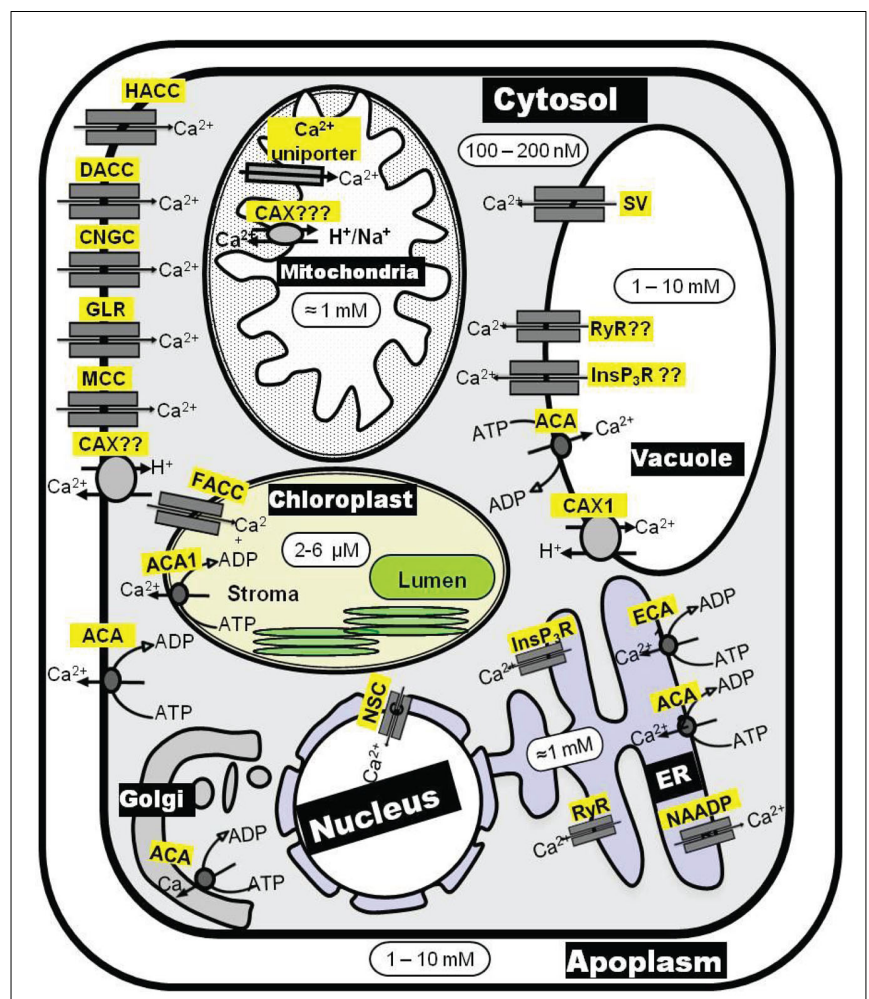

FIGURE 2 | Schematic diagram of $\mathrm{Ca}^{2+}$ transporters involved in $\mathrm{Ca}^{2+}$ homeostasis maintenance inside the plant cell. ACA, autoinhibited calcium ATPase; CAX, calcium exchanger; CNGC, cyclic nucleotide gated channel; DACC, depolarization activated cation channel; ECA, ER-type calcium ATPase; FACC, fast-activating cation channel; GLR, glutamate receptor-like channel; $A C C$, hyperpolarization activated cation channel; InsP3R, inositol 1,4,5-trisphosphate receptor-like channel; MCC, mechanosensitive cation channel; NSC, non-selective cation channel; RyR cyclic ADP-ribose (cADPR)-activator ryanodine receptor-like channel; SV, slow-activating vacuolar channel.

and Hirschi, 2003; Shigaki and Hirschi, 2006; Boursiac and Harper, 2007). Despite this fact, the role of specific $\mathrm{Ca}^{2+}$ efflux systems has never been included in any $\left[\mathrm{Ca}^{2+}\right]_{\mathrm{cyt}}$ signaling model.

\section{MOLECULAR IDENTITY OF CALCIUM EFFLUX SYSTEMS $\mathrm{CA}^{2+}$-ATPASES}

$\mathrm{Ca}^{2+}$-ATPases are energized directly by ATP and belong the super family of P-type ATPases, ion pumps that are ubiquitous in all life forms. A hallmark of P-type ATPases is that they form a phosphorylated reaction cycle intermediate during catalysis. Two types of $\mathrm{Ca}^{2+}$-ATPases are known in plants: $\mathrm{P}_{2 \mathrm{~A}}$-ATPase [or ER-type $\mathrm{Ca}^{2+}$ ATPase (ECA)] and $\mathrm{P}_{2 \mathrm{~B}}$-ATPase [or autoinhibited $\mathrm{Ca}^{2+}$-ATPase (ACA); Geisler et al., 2000; Sze et al., 2000]. The structurally most distinctive difference between plant P2A- and P2B-ATPases is the extended $\mathrm{N}$-terminus of $\mathrm{P} 2 \mathrm{~B}$-ATPases, which serves a role as an autoinhibitor of pump activity and binds calmodulin. Four members of ECA (ECA 1-4) and 10 members of ACA (ACA1-10) have been identified in Arabidopsis (Sze et al., 2000).

ACAs can be present in the PM as well as in endomembranes whereas ECAs are exclusively localized to endomembranes. The cellular locations of ACAs and ECAs in Arabidopsis are depicted in Figure 2. (i) ACA8 (Bonza et al., 2000), ACA9 (Schiøtt et al., 2004) and ACA10 (George et al., 2008) reside at the PM, (ii) ACA4 (Geisler et al., 2000) and ACA11(Lee et al., 2007) at the tonoplast, (iii) ECA 1 (Liang et al., 1997) and ACA2 (Harper et al., 1998) at the ER, (iv) ECA 3 at the Golgi (Mills et al., 2008) and endosomes (Li et al., 2008), and (v) ACA1 at the plastid envelope (Huang et al., 1993). Apart from ACAs and ECAs, a $\mathrm{P}_{1}$-ATPase (HMA1) has been implicated in acting as a $\mathrm{Ca}^{2+}$ /heavy metal pump at the chloroplast envelope (Moreno et al., 2008).

\section{CA $^{2+}$ EXCHANGERS}

$\mathrm{Ca}^{2+}$ exchangers are energized by the counter transport of another cation, usually $\mathrm{H}^{+}$or $\mathrm{Na}^{+}$. In Arabidopsis, six CAX genes (AtCAX1 to AtCAX6) that encode $\mathrm{H}^{+} / \mathrm{Ca}^{2+}$ exchangers plus five $\mathrm{CCX}$ (cation/ $\mathrm{Ca}^{2+}$ exchangers, previously described as AtCAX7 to AtCAX11) that encode $\mathrm{K}^{+}$-dependent $\mathrm{Na}^{+} / \mathrm{Ca}^{2+}$ exchangers, have been identified to date (Mäser et al., 2001; Shigaki et al., 2006). The function of CAX (CAX1 to CAX4) in the tonoplast is widely studied (Hirschi, 1999; Hirschi et al., 2000; Cheng et al., 2002a, 2003, 2005); CAX activity at the PM is also reported (Kasai and Muto, 1990; Luo et al., 2005).

\section{REGULATION OF CALCIUM EFFLUX SYSTEMS ACTIVITY $\mathrm{CA}^{2+}$-ATPASE REGULATION}

$\mathrm{Ca}^{2+}$-ATPases are activated by submicromolar concentrations of $\mathrm{Ca}^{2+}$. For this reason they are defined as high-affinity pumps (Møller et al., 2010). Due to tight coupling between ion binding and ATP hydrolysis, ATP hydrolysis will never take place if $\mathrm{Ca}^{2+}$ has not been bound in the membranous region of the $\mathrm{Ca}^{2+}$. ATPase (Morth et al., 2011). Likewise, hydrolysis of ATP is always associated with transport of $\mathrm{Ca}^{2+}$.

As $\left[\mathrm{Ca}^{2+}\right]_{\text {cyt }}$ increases in response to environmental stress, $\mathrm{Ca}^{2+}$-ATPases are immediately activated as a result of $\mathrm{Ca}^{2+}$ binding to their transport sites. P2A-ATPases have two $\mathrm{Ca}^{2+}$ binding sites in their membrane domain both of which have to be occupied before ATP hydrolysis can occur (Møller et al., 2010). In contrast, P2B-ATPases have a single membranous $\mathrm{Ca}^{2+}$ binding site (Brini and Carafoli, 2009) and therefore can proceed to ATP hydrolysis directly after $\mathrm{Ca}^{2+}$ binding. Further, in contrast to $\mathrm{P} 2 \mathrm{~A} \mathrm{Ca}^{2+}$. ATPases, P2B-ATPases are equipped with a $\mathrm{Ca}^{2+}$ sensor that allows the pump to change its activation state depending on $\left[\mathrm{Ca}^{2+}\right]_{\mathrm{cyt}}$ (see below). These combined features make P2B-ATPases optimal for responding to increased $\left[\mathrm{Ca}^{2+}\right]_{c y t}$.

The sensor function of $\mathrm{P} 2 \mathrm{~B} \mathrm{Ca}{ }^{2+}$-ATPases is achieved by the ability of a terminal autoinhibitory domain to bind calmodulin. A calmodulin binding site was first identified in the C-terminal domain of an animal P2B Ca ${ }^{2+}$-ATPase (James et al., 1988) and later found in the $\mathrm{N}$-terminal domain of a plant $\mathrm{P} 2 \mathrm{~B} \mathrm{Ca}^{2+}$-ATPase (Malmström et al., 1997). We now know that the N-terminal localization of an autoinhibitory calmodulin binding domain is a distinctive feature of plant P2B Ca ${ }^{2+}$-ATPases (Geisler et al., 2000; Boursiac and Harper, 2007). The calmodulin protein binds four $\mathrm{Ca}^{2+}$ ions cooperatively and as a result changes from a loose to a compact conformation when binding to the $\mathrm{Ca}^{2+}$ pump (Ishida and Vogel, 2010). The calmodulin binding site of the $\mathrm{N}$-terminus of $\mathrm{P} 2 \mathrm{~B} \mathrm{Ca} \mathrm{Ca}^{2+}$-ATPases is thought to interact with a cytoplasmic domain of the pump in this way restricting domain 
movements and pump function (Luoni et al., 2004). The sequence of amino acid residues that serves as a calmodulin binding site also functions as a pump autoinhibitor (Baekgaard et al., 2006). This suggests that, as calmodulin binds $\mathrm{Ca}^{2+}$, its affinity for the $\mathrm{N}$ terminal calmodulin binding site increases and, when fully loaded with $\mathrm{Ca}^{2+}$, calmodulin competes favorably with the intramolecular binding site for the autoinhibitor and, as the autoinhibitory sequence becomes neutralized by calmodulin with bound $\mathrm{Ca}^{2+}$, the $\mathrm{N}$-terminal autoinhibition is relieved. In addition to calmodulin, other cellular components such as acidic phospholipids might influence the autoinhibitory effect of the N-terminal domain (Bonza and De Michelis, 2011).

The presence of a regulatory terminal domain in $\mathrm{P} 2 \mathrm{~B} \mathrm{Ca}^{2+}$ ATPases is not a unique feature of these pumps. The plant PM $\mathrm{H}^{+}$-ATPase has an extended C-terminal domain with two autoinhibitory sequences (Axelsen et al., 1999) and the PM heavy metal pump HMA4 has an extended C-terminal domain that serves as a $\mathrm{Zn}^{2+}$ and $\mathrm{Cd}^{2+}$ sensor (Baekgaard et al., 2010). Both these pumps belong to the P-type ATPase superfamily. How are $\mathrm{P} 2 \mathrm{~A} \mathrm{Ca}^{2+}$ ATPases with very short terminal domains then regulated? At least in animal cells, they interact with inhibitory subunits that are small membrane proteins (Palmgren and Nissen, 2011). Whether in a similar way plant P2A-ATPases are post-translationally regulated by associated subunits remains to be shown.

\section{CAX REGULATION}

Plant cation $/ \mathrm{H}^{+}$exchangers, like plant $\mathrm{Ca}^{2+}$-ATPases, appear to be primarily regulated at the post-translational level, although some form of transcriptional regulation may occur (Shigaki et al., 2010; Manohar et al., 2011). CAX1 may be regulated via an N-terminal autoinhibitory domain, which binds to an adjacent region within the N-terminus (Pittman et al., 2002; Mei et al., 2007). Other forms of regulation via (i) formation of a "hetero-CAX" complex through interaction between CAX1 and CAX3 (Zhao et al., 2009); (ii) phosphorylation (Pittman et al., 2002), or (iii) various CAX interacting proteins (CXIP) including CXIP4 and the Ser/Thr Kinase SOS2 (Cheng and Hirschi, 2003; Cheng et al., 2004a,b) and/or (iv) pH homeostasis (Zhao et al., 2008) have also been observed.

\section{CONTROL OF CA ${ }^{2+}$ ATPASES BY POLYAMINES AND ROS}

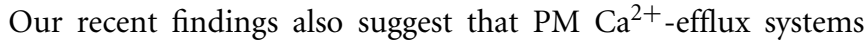
may be regulated by synergistic effects of polyamines (PAs) and hydroxyl-radicals $\left(\mathrm{OH}^{\bullet}\right)$. The levels of both $\mathrm{PA}$ and $\mathrm{OH}^{\bullet}$ are known to increase dramatically under stress conditions. Also, PAs block a variety of $\mathrm{K}^{+}$and non-selective cation channels in plants (Dobrovinskaya et al., 1999; Liu et al., 2000; Shabala et al., 2007; Zhao et al., 2007), whereas $\mathrm{OH}^{\bullet}$ and $\mathrm{H}_{2} \mathrm{O}_{2}$ activate different $\mathrm{PM} \mathrm{Ca}^{2+}$ influx channels (Pei et al., 2000; Demidchik et al., 2003, 2007), thus affecting cytosolic ionic homeostasis. There is also a cross-talk between ROS and PAs, as several types of plant responses to environmental clues such as salt or drought involve PAs export to apoplast and further oxidation by available diamineor polyamine-oxidase, resulting in $\mathrm{H}_{2} \mathrm{O}_{2}$ and $\mathrm{OH}^{\bullet}$ formation and activation of the $\mathrm{Ca}^{2+}$ influx across the PM (An et al., 2008; Moschou et al., 2008).
In our work, $\mathrm{OH}^{\bullet}(1 \mathrm{mM} \mathrm{Cu} /$ ascorbate $)$ treatment evoked a long-lasting $\mathrm{Ca}^{2+}$ influx into pea roots due to $\mathrm{OH}^{\bullet}$-induced nonselective passive conductance. However, at shorter times, transient $\mathrm{Ca}^{2+}$ efflux was measured to be sensitive to eosine yellow, a specific $\mathrm{Ca}^{2+}$ pump inhibitor (data not shown). Lowering the amount of $\mathrm{OH}^{\bullet}\left(0.1 \mathrm{mM} \mathrm{Cu}\right.$ /ascorbate) shifted the balance between $\mathrm{Ca}^{2+}$ uptake and efflux toward net efflux (Figure 3), implying a lower threshold for the $\mathrm{OH}^{\bullet}$-inducible $\mathrm{Ca}^{2+}$ efflux system as compared to the $\mathrm{Ca}^{2+}$ influx one. Addition of either $1 \mathrm{mM} \mathrm{Spm}^{4+}$ or $\mathrm{Put}^{2+}$ provoked a massive net $\mathrm{Ca}^{2+}$ efflux with very similar kinetics and magnitude (Figure 3). Integrating this flux over the period of $30 \mathrm{~min}$ and taking into account the root geometry and dimensions, we estimated that the total intracellular $\mathrm{Ca}^{2+}$ loss was equivalent to $0.2 \mathrm{mM}$ for $\mathrm{OH}^{\bullet}$ treatment, and $\sim 0.6 \mathrm{mM}$ for PAs. The latter value may be even in excess of the total cytosolic $\mathrm{Ca}^{2+}$, implying the mobilization of the vacuolar pool.

To the best of our knowledge, PAs effects on $\mathrm{Ca}^{2+}$ pumps have never been reported. However, PAs are known to stimulate another P-type pump, $\mathrm{H}^{+}$-ATPase, presumably via interaction of autoinhibitory domain protein with 14-3-3 proteins (Garufi et al., 2007). PAs may also activate the $\mathrm{H}^{+}$-pump via an $\mathrm{NO}$-dependent pathway (Tun et al., 2006; Arasimowicz-Jelonek et al., 2009; Zandonadi et al., 2010). Another interesting possibility is that this comes about due to formation of a complex of $\mathrm{Mg}^{2+}$-ATP-spermine, which seems to present an increased rate for catalysis by ATPases as compared to $\mathrm{Mg}^{2+}$-ATP (Meksuriyen et al., 1998). It may also be possible that PAs stimulate the $\mathrm{PM} \mathrm{H}^{+}$pump, which indirectly affects/stimulates the $\mathrm{Ca}^{2+}$ pump in an $\mathrm{H}^{+}$-coupled mechanism.

There is a large body of data on animal $\mathrm{PM} \mathrm{Ca}^{2+}$-pumps (PMCA), showing their inhibition by ROS resulting from protein cross-linking, lipid peroxidation, and concurrent inhibition by an oxidized form of calmodulin (Waring, 2005). However, these effects develop slowly (time scale of hours) and, thus, could not be responsible for the rapid induction of net $\mathrm{Ca}^{2+}$ efflux in our

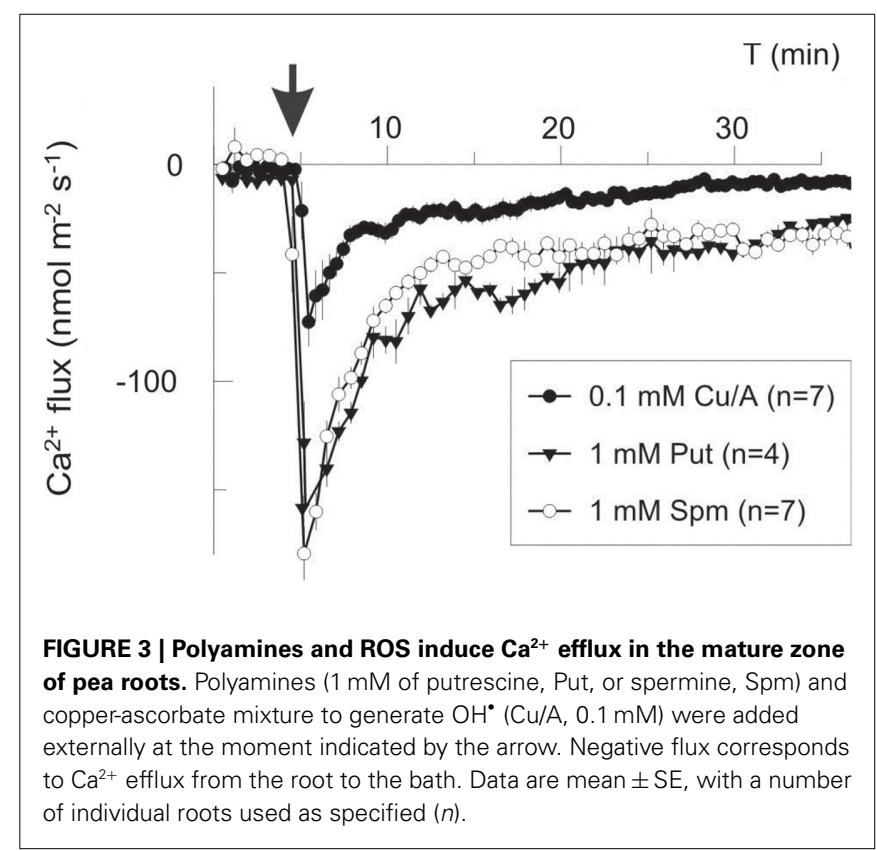


experiments. On the contrary, for plants a rapid activation of $\mathrm{Ca}^{2+}$-ATPase by ROS via the CaM-Ca ${ }^{2+}$ binding complex, has been described (Romani et al., 2004). However, the observation of a net $\mathrm{Ca}^{2+}$ efflux at lower ROS generated levels $(0.1 \mathrm{mM} \mathrm{Cu} / \mathrm{A}$; Figure 3) implies that the activation of $\mathrm{Ca}^{2+}$ pumping in this case is an early event, independent on the $\mathrm{Ca}^{2+}$-pump activation via $\mathrm{Ca}^{2+}-\mathrm{CaM}$.

It should be also mentioned that PAs are readily catabolized in the apoplast, releasing $\mathrm{H}_{2} \mathrm{O}_{2}$, which could be further converted to $\mathrm{OH}^{\bullet}$ by apoplastic peroxidases iron and/or diamine oxidases copper (Liszkay et al., 2004; Kukavica et al., 2009). A possible contribution of this mechanism should be validated in direct experiments.

\section{INCORPORATING CALCIUM EFFLUX SYSTEMS INTO EXISTING SIGNALING MODELS EXPERIMENTAL EVIDENCE}

Although transient increases in $\left[\mathrm{Ca}^{2+}\right]_{c y t}$ are essential for plant responses to a variety of environmental stimuli, long-lasting elevations in $\left[\mathrm{Ca}^{2+}\right]_{\text {cyt }}$ are harmful for cells. Hence, the basal conditions must be restored back to resting level after the signal is completed, enabling cells to react to further signals (Sanders et al., 1999; Beffagna et al., 2005). In animal systems, active $\mathrm{Ca}^{2+}$ efflux systems have been widely implicated in a wide range of stress responses (e.g., Jornot et al., 1999; Zaidi and Michaelis, 1999). Much less is known about the involvement of $\mathrm{Ca}^{2+}$ efflux systems in stress responses in plant cells. We believe this is wrong, and argue that active $\mathrm{Ca}^{2+}$ efflux systems must be incorporated in all stress signaling models.

\section{Biotic stresses}

Intracellular calcium signaling is universally accepted as a key component of plant biotic stress defense mechanisms (Grant et al., 2000; Lam et al., 2001, Pike et al., 2005). Elicitor-induced elevations in $\left[\mathrm{Ca}^{2+}\right]_{\text {cyt }}$ were reported during hypersensitive (HR) plant-pathogen interactions (Nurnberger et al., 1994; Blume et al., 2000; Lecourieux et al., 2002); these are believed to be essential for the development of the oxidative burst needed to trigger the activation of several plant defense reactions (Blumwald et al., 1998; Lecourieux et al., 2002). It was shown that $\mathrm{Ca}^{2+}$ channel blockers inhibit HR in many species (Atkinson et al., 1990; Levine et al., 1996), suggesting that PM-mediated calcium influx is required for HR initiation. As a result, most preceding reports were focused on the role of calcium cannels in HR induction (Atkinson et al., 1990; Levine et al., 1996, Jabs et al., 1997; Grant et al., 2000, Lam et al., 2001; Balagué et al., 2003, Pike et al., 2005; Hann and Rathjen, 2007). However, recent experiments in our laboratory have suggested that pathogen-induced $\mathrm{Ca}^{2+}$ influx occurs only at the first stages of pathogen-host interaction, during $0-7 \mathrm{~h}$ after the challenge (Nemchinov et al., 2008). Using P. syringae-inoculated tobacco plants we have shown that the initial calcium uptake is subsequently followed by the net calcium efflux initiated between 10 and $12 \mathrm{~h}$ and continued up to $48 \mathrm{~h}$ after the pathogen challenge. This efflux was inhibited by cyclopiazonic acid, a known inhibitor of $\mathrm{Ca}^{2+}$-ATPase, suggesting that active $\mathrm{Ca}^{2+}$ efflux systems play an important role in HR. A new model of a multi-step HR process has been put forward (Nemchinov et al., 2008). According to this model, prolonged $\mathrm{Ca}^{2+}$ uptake, which continues to occur $1-7 \mathrm{~h}$ after the challenge, reflects the pathogen's successful overcoming the initial PAMP-triggered defense reaction, and sustained increases in $\left[\mathrm{Ca}^{2+}\right]_{\mathrm{cyt}}$ at this stage are necessary for generation of ROS, oxidative burst, and induction of HR (Atkinson et al., 1990; Grant et al., 2000). After HR transduction pathway has been initiated with the help of $\mathrm{Ca}^{2+}$ uptake, $\left[\mathrm{Ca}^{2+}\right]_{\text {cyt }}$ levels sharply decline to mediate the last HR phase - an expanded cell death.

We have also recently demonstrated that $\mathrm{Ca}^{2+}$ efflux systems play a crucial role in the phenomenon of acquired crosstolerance to oxidative stress in plants. Nicotiana benthamiana plants were infected with Potato virus $X$ (PVX) and exposed to oxidative (either UV-C or $\mathrm{H}_{2} \mathrm{O}_{2}$ ) stress. It was shown that virus-infected plants had a better ability to control UV-induced elevations in $\left[\mathrm{Ca}^{2+}\right]_{\mathrm{cyt}}$ free $\mathrm{Ca}^{2+}$ and prevent structural and functional damage of chloroplasts (Shabala et al., 2011a), and that PM $\mathrm{Ca}^{2+}$ efflux systems play a critical role in this process. Several major lines of evidence support this conclusion: (1) significant net $\mathrm{Ca}^{2+}$ efflux was measured from UV-treated leaves $2 \mathrm{~h}$ after stress exposure. As passive $\mathrm{Ca}^{2+}$ leak from the cytosol is thermodynamically impossible, such efflux cannot be attributed to the general change in PM permeability and may be explained only by the activation of some $\mathrm{Ca}^{2+}$ efflux (active) system at the PM (e.g., either $\mathrm{Ca}^{2+}$-ATPases or $\mathrm{Ca}^{2+} / \mathrm{H}^{+}$exchanger); (2) PVX-inoculated leaves were actively pumping $\mathrm{Ca}^{2+}$ out (net efflux) while mock controls were still taking up $\mathrm{Ca}^{2+}$; (3) PVXinoculated cells have a much better capacity to activate $\mathrm{PM} \mathrm{Ca}{ }^{2+}$ efflux systems to deal with UV-induced elevation in $\left[\mathrm{Ca}^{2+}\right]_{\mathrm{cyt}}$ thereby preventing damage to chloroplast structure (Shabala et al., 2011a).

To separate the different types of active $\mathrm{Ca}^{2+}$ transport systems, a series of pharmacological experiments was conducted. Neither erythrosine $\mathrm{B}$ nor eosin yellow (EY), two known inhibitors of $\mathrm{P}_{2 \mathrm{~B}}$ type $\mathrm{Ca}^{2+}$-ATPases, had a significant impact on the magnitude of net $\mathrm{Ca}^{2+}$ fluxes from tobacco mesophyll segments (Shabala et al., 2011a). Also unaffected was $\mathrm{Ca}^{2+}$-ATPase activity in purified PM vesicles from tobacco leaves. This suggested that the PM $\mathrm{Ca}^{2+}$-ATPases play a limited (if any) role in mediating $\mathrm{Ca}^{2+}$ efflux under oxidative stress conditions and suggested that the latter is mediated by $\mathrm{PM} \mathrm{Ca}{ }^{2+} / \mathrm{H}^{+}$exchangers.

Not only plasma but also endomembrane $\mathrm{Ca}^{2+}$ efflux systems mediate the phenomenon of cross-protection in plants. Using biochemical and electrophysiological approaches, it was revealed that both endomembrane $\mathrm{P}_{2 \mathrm{~A}}$ and $\mathrm{P}_{2 \mathrm{~B}} \mathrm{Ca}^{2+}$-ATPases play significant roles in adaptive responses to oxidative stress by removing excessive $\mathrm{Ca}^{2+}$ from the cytosol, and that their functional expression is significantly altered in PVX-inoculated plants (Shabala et al., 2011b). Taken together, these findings highlight the crucial role of $\mathrm{Ca}^{2+}$ efflux systems in acquired tolerance to oxidative stress and open up prospects for practical applications in agriculture.

\section{Abiotic stresses}

The evidence for the importance of $\mathrm{Ca}^{2+}$-ATPase in shaping $\left[\mathrm{Ca}^{2+}\right]_{\text {cyt }}$ signatures came from two independent salinity studies. First, knocking out both AtACA4 and AtACA2 in Saccharomyces cerevisiae can increase $\mathrm{NaCl}$ sensitivity, but expression of AtACA4 or AtACA2 can provide tolerance to $\mathrm{NaCl}$. Moreover, $\left[\mathrm{Ca}^{2+}\right]_{\mathrm{cyt}}$ 
elevations upon salinity stress are brought back to resting levels quickly, by expression of AtACA2 in this yeast mutant (Anil et al., 2008). Secondly, in moss (Physcomitrella patens), salinity stress to a loss-of-function mutant of ACA type ATPase (PCA1), resulted in sustained $\left[\mathrm{Ca}^{2+}\right]_{\text {cyt }}$ elevation and never returned to resting level (Qudeimat et al., 2008). ACAs may also e involved in $\left[\mathrm{Ca}^{2+}\right]_{\mathrm{cyt}}$ signal shaping in response to other stresses. For example, AtACA 8 was found to be unregulated, whereas AtACA10 was found be down regulated in response to cold stress (Schiøtt and Palmgren, 2005).

Earlier Romani et al. (2004) showed that submicromolar concentrations of EY (a $\mathrm{P}_{2 \mathrm{~B}}$-type $\mathrm{Ca}^{2+}$-ATPase inhibitor) prevented both the increase in $\mathrm{Ca}^{2+}$ efflux and the transient ROS accumulation in Egeria densa in response to ABA treatment. This result was explained by assuming an important role of $\mathrm{PM} \mathrm{Ca}^{2+}$-ATPase in switching off the signal triggering ROS production. Another report from the same group implicated $\mathrm{PM} \mathrm{Ca}{ }^{2+}$-ATPase activation in plant adaptation to osmotic stress (Beffagna et al., 2005). Interestingly, knocking out caxl resulted in increased freezing tolerance (Catalá et al., 2003) but knocking out cax3 resulted in an increased sensitivity to salinity (Zhao et al., 2008), suggesting that each stress targets a particular CAX transporter within the CAX family. Stress-induced $\left[\mathrm{Ca}^{2+}\right]_{\text {cyt }}$ measurements involving cax knock out mutants may provide more insight into the specific role of each CAX transporter in shaping $\left[\mathrm{Ca}^{2+}\right]_{\mathrm{cyt}}$ signals.

\section{THEORETICAL CONSIDERATIONS AND MODELING}

The importance of $\mathrm{Ca}^{2+}$ efflux systems in shaping $\mathrm{Ca}^{2+}$ signatures is further investigated by modeling stimulus-induced changes in $\left[\mathrm{Ca}^{2+}\right]_{\text {cyt }}$. As a starting point, we use the model of Stucki and Somogyi (1994), as adopted by Bauer et al. (1998). This model includes four major components: two $\mathrm{Ca}^{2+}$-permeable channels $(A$ and $C)$, located respectively at the plasma - and endomembranes, and two active $\mathrm{Ca}^{2+}$ efflux systems: PM-based $\mathrm{Ca}^{2+}$-ATPase pump $(B)$ and endomembrane-based $\mathrm{Ca}^{2+} / \mathrm{H}^{+}$exchanger ( $D$; Figure 4). Unlike the Bauer et al. (1998) model, we assume no leakage from the cytosol. We also assume that activity of endomembrane $\mathrm{Ca}^{2+}$ channel is dependent on ROS accumulation in the cytosol; this is parametrized by factor $R$.

The amount $y$ of $\mathrm{Ca}^{2+}$ in the cytosol, and $x$ in the intracellular store is then given by (cf. Stucki and Somogyi, 1994):

$$
\begin{aligned}
\frac{d y_{\text {total }}}{d t} & =A-(B+D) y_{\text {free }}+\left(C \frac{\left(y_{\text {free }}+R\right)^{n}}{K+\left(y_{\text {free }}+R\right)^{n}}\right)\left(x-y_{\text {free }}\right) \\
\frac{d x}{d t} & =D y_{\text {free }}-\left(C \frac{\left(y_{\text {free }}+R\right)^{n}}{K+\left(y_{\text {free }}+R\right)^{n}}\right)\left(x-y_{\text {free }}\right)
\end{aligned}
$$

Here $y_{\text {total }}$ denotes the total $\mathrm{Ca}^{2+}$ in the cytosol. This includes both bound and free calcium.

The mechanistic (biological) meaning of these equations is as follows. In Eq.(1), the rate of change of $\mathrm{Ca}^{2+}$ in the cytosol $d y_{\text {total }} / d t$ is affected by both channels $(A$ and $C)$ and both active $\mathrm{Ca}^{2+}$-efflux systems $(B$ and $D)$. The latter drive an efflux of $\mathrm{Ca}^{2+}$ from the cytosol (hence the minus sign), and this efflux is proportional to the concentration $y_{\text {free }}$ of free cytosolic $\mathrm{Ca}^{2+}$. Influx

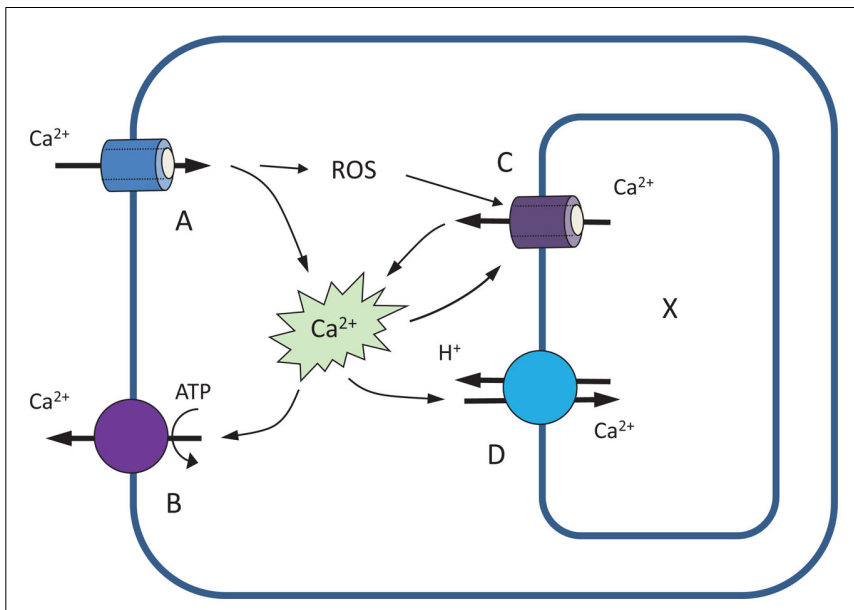

FIGURE 4 | A four-component model illustrating the role of $\mathrm{Ca}^{2+}$ efflux systems in shaping up $\mathrm{Ca}^{2+}$ signatures (based on Stucki and Somogyi, 1994; Bauer et al., 1998). See text for explanations.

of $\mathrm{Ca}^{2+}$ into the cytosol is driven by a concentration gradient between external calcium and the cytosol (assumed to be a constant $A$, since the external calcium is typically plentiful); and an efflux from the intracellular store, driven by the concentration gradient $\left(x-y_{\text {free }}\right)$. The functional form for the multiplicative factor for $C$ is given by the Hill equation, modified to include ROS accumulation (parametrized by $R$ ). Physically it corresponds to buffering-type kinetics.

In Eq.(2), the rate of change of intracellular store $\mathrm{Ca}^{2+}$ concentration, $d x / d t$, is then governed by an efflux due to channel $C$ that is equal in magnitude but opposite in sign to the influx into the cytosol as described in Eq.(1); and an influx proportional to the free cytosolic $\mathrm{Ca}^{2+}$ concentration due to pump $D$.

The buffering capacity of the cytosol is described by MichaelisMenten kinetics as

$\frac{y_{\text {total }}}{y_{\text {free }}}=1+\left(\frac{B_{\max }}{y_{\text {free }}+K_{\mathrm{d}}}\right)$

The left-hand side of Eq.(1) can then be expressed in terms of $y_{\text {free, }}$

$$
\begin{aligned}
& \frac{d y_{\text {free }}}{d t}\left(1+\frac{B_{\max } K_{d}}{\left(y_{\text {free }}+K_{d}\right)^{2}}\right) \\
& =A-(B+D) y_{\text {free }}+\left(C \frac{\left(y_{\text {free }}+R\right)^{n}}{K+\left(y_{\text {free }}+R\right)^{n}}\right)\left(x-y_{\text {free }}\right)
\end{aligned}
$$

and the expression for amount $x$ in the intracellular store remains unchanged.

\section{Model parameters}

The equations above are scalable. $A$ has dimensions of (amount/time); $B, C$, and $D$ have dimension ( $1 /$ time); $K$ is in [amount $^{(1 / n)}$ ]; $B_{\max }, K_{\mathrm{d}}$ and $R$ are in (amount), just as $x$ and $y$. This means that the scaled quantities can be related to physical 
ones via the initial conditions, $x(t=0)$ and $y(t=0)$ which are given in moles.

The scaling comes from available experimental data for $\mathrm{Ca}^{2+}$ flux into the cell. Assuming net $\mathrm{Ca}^{2+}$ influx (through $A$ ) into the cell being $\sim 60 \mathrm{nmol} / \mathrm{m}^{2} / \mathrm{s}$ (e.g., as in response to ROS treatment; Demidchik et al., 2002, 2007) and cell diameter of $30 \mu \mathrm{m}$, then the total amount of $\mathrm{Ca}^{2+}$ influx will be $10^{-6} \mathrm{~mol} / \mathrm{L}$, giving a physical flux $A_{\text {phys }}=2 \mu \mathrm{M} / \mathrm{s}$. Hence, measuring concentrations in micrometer and time in seconds, we set for our default model $A=2$. Assuming $\left[\mathrm{Ca}^{2+}\right]_{\text {cyt }}$ equal $100 \mathrm{nM}$ and $\mathrm{Ca}^{2+}$ concentration inside the internal organelles within $100-1000 \mu \mathrm{M}$ range (Medvedev, 2005), we adopt $y(t=0)=0.1$ and $x(t=0)=160$.

As in Bauer et al. (1998) we assume $n=4, K=1$. To set the buffering parameters we use the physical values of $B_{\max , \text { phys }}=0.2-$ $0.5 \mathrm{mM}$ (Trewavas, 1999 ) and $K_{\mathrm{d} \text {,phys }}=0.15-0.6 \mu \mathrm{M}$ (MartinezSerrano et al., 1992; Kuratomi et al., 2003). This translates to adopted scaled quantities of $B_{\max }=200-500$ and $K_{\mathrm{d}}=0.15-0.6$. For the default model, we adopt $B_{\max }=250$ and $K_{\mathrm{d}}=0.6$.

The time scaling relates to constants $A, B, C$, and $D$. $A$ is simply the uptake rate of $\mathrm{Ca}^{2+}$ from external media, and has dimensions of (amount/time); and units of $[\mu \mathrm{M} / \mathrm{s}] . B, C$, and $D$ are essentially the inverse of decay-like constants, with dimensions of (1/time). This is easy to see from a simplified version of Equation 1, where each of these variables is described by a term like $(d y / d t) \propto B y$, etc. The solution to such a differential equation is an exponential, $y \propto \mathrm{e}^{B t}$, and so $1 / B$ is the time it takes for the amount of "stuff" to drop/increase by a factor of e $(=2.718)$.

As discussed above, the time scaling of $A$ is set by the physical parameter describing the influx into the cell (provided no other mechanisms were operating). In our default model $A=2$, which corresponds to a flux of $2 \mu \mathrm{M} / \mathrm{s}$. Setting $A$ in this way means the values of $B, C$, and $D$ are fixed by what "decay" constants are biologically meaningful.

\section{Qualitative behavior}

We explore the qualitative behavior of the model and contribution of activities of $\mathrm{Ca}^{2+}$-ATPase pump and $\mathrm{Ca}^{2+} / \mathrm{H}^{+}$ exchanger to the kinetics of $\left[\mathrm{Ca}^{2+}\right]_{\text {cyt }}$. This is done using larger timescales to reflect the oscillatory behavior of $\left[\mathrm{Ca}^{2+}\right]_{\mathrm{cyt}}$ changes. In doing this, we loosely follow the ratios between values adopted by Bauer et al. (1998) and assume the following set parameters: $A=2 ; B=20 ; C=60 ; D=36 ; R=0.05$; $B_{\max }=250 ; K_{\mathrm{d}}=0.6$. We also give the initial conditions $y(t=0)=0.1 ; x(t=0)=160$. As explained below, this set of parameters is motivated by experimental results. We then vary each of the parameters $B$ and $D$ in turn, typically through a dynamic range of a few, around the "default" value. Table 1 summarizes the various parameters and their typical values. Results are shown in Figure 5 and described below.

Looking at timescales of a few minutes, increase in the activity of either the PM $\mathrm{Ca}^{2+}$-ATPase pump $B$ or the $\mathrm{Ca}^{2+} / \mathrm{H}^{+}$exchanger $D$, results in a longer oscillation timescale, and sharper peaks in cytosol concentration (Figures 5A,C). Importantly, as one can see, the physiologically relevant set of parameters in our model reproduces oscillation timescales of a few minutes as reported by many experimental studies (reviewed in McAinsh and Hetherington, 1998; Ng and McAinsh, 2003; McAinsh and Pittman, 2009; Roelfsema and Hedrich, 2010).

Shorter-term behavior allows us to decouple the pump/exchanger contributions. The exchanger $D$ only shifts the location of the first peak (Figure 5D), while the pump B both shifts the peak and changes the speed with which the cytosol concentration drops (Figure 5B) - the "decay constant" discussed in the previous section. Thus, pumps and exchangers appear to have a different role in shaping $\left[\mathrm{Ca}^{2+}\right]_{\mathrm{cyt}}$ signatures.

Table 1 | Model parameters.

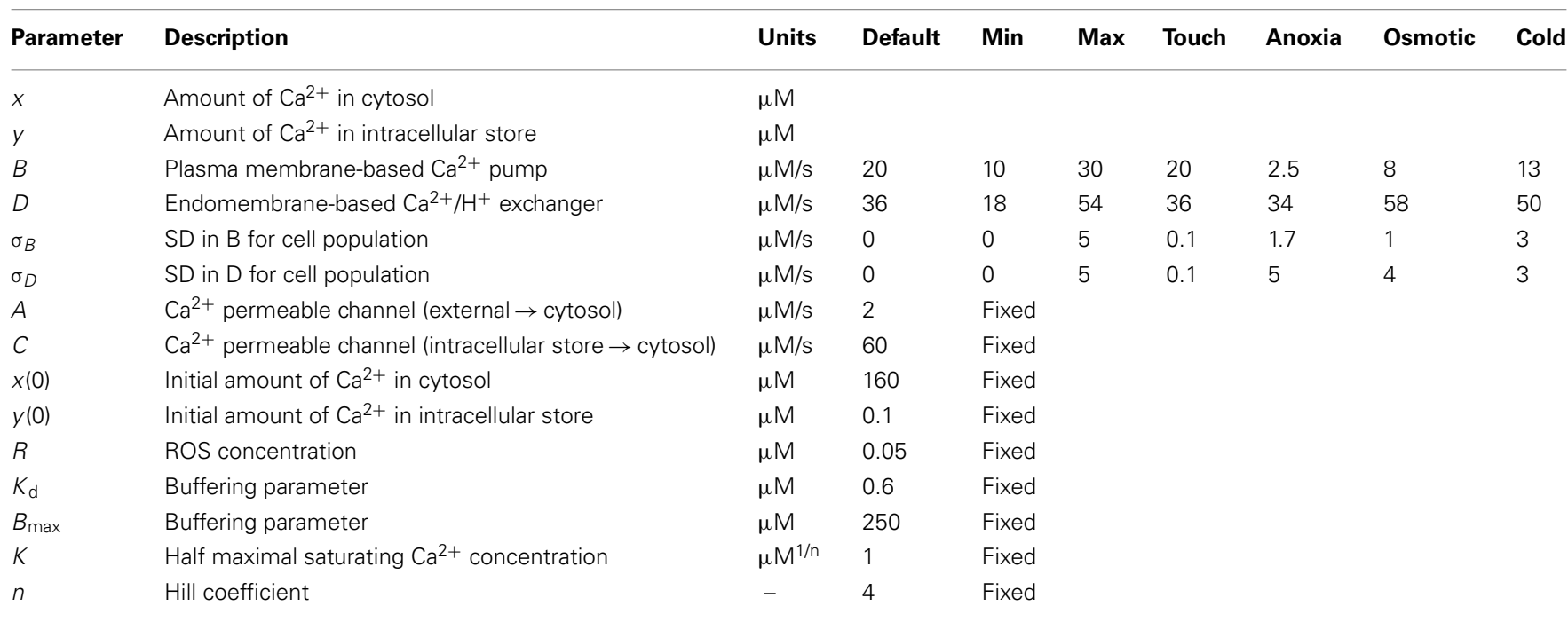

The "default" model is the reference model. Parameters $B, D, \sigma_{B}$, and $\sigma_{D}$ are changed in the range minimum - maximum and plotted in Figures $\mathbf{5}$ and $\mathbf{6}$. Best fit parameters for touch, cold, anoxia, and osmotic stress correspond to curves in Figure 7. All other model parameters are held constant in this work. 

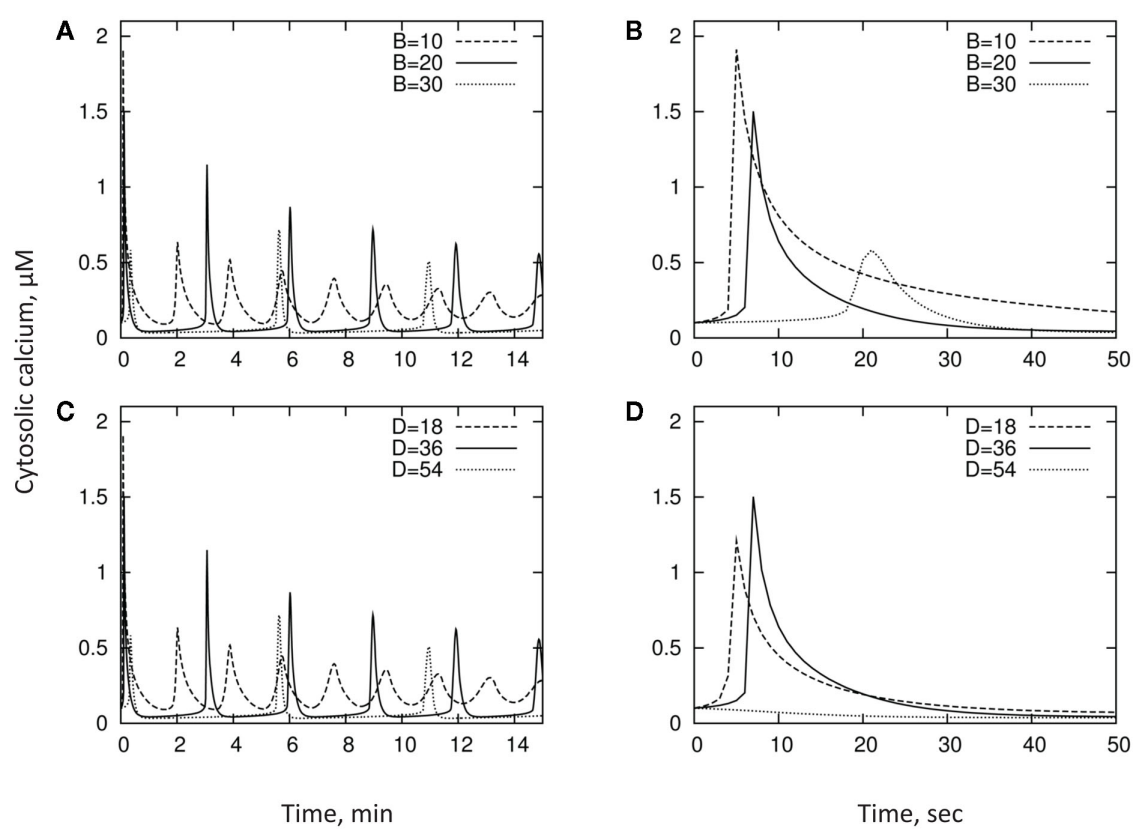

FIGURE 5 | Qualitative behavior of the model and contribution of activities of $\mathrm{Ca}^{2+}$-ATPase pump and $\mathrm{Ca}^{2+} / \mathrm{H}^{+}$exchanger to the kinetics of $\left[\mathrm{Ca}^{2+}\right]_{\mathrm{cyt}}$. The exchanger $D$ [shown in panel (C) and zoomed in panel (D)] shifts the location of the first peak, while the pump $B$ [shown in panel (A) and zoomed in panel (B)] alters both the peak location and the speed with which $\left[\mathrm{Ca}^{2+}\right]_{\text {cyt }}$ drops.

\section{Accounting for spatial heterogeneity}

Stimulus-induced elevations in $\left[\mathrm{Ca}^{2+}\right]_{\text {cyt }}$ usually show marked spatial heterogeneities, displaying both "hot-spots" and $\mathrm{Ca}^{2+}$ quiescent regions (Gilroy et al., 1991; McAinsh et al., 1995; Ng and McAinsh, 2003). It was suggested that such spatial heterogeneity could result from either different accessibility of the primary stimulus to only a subset of the signaling machinery, or the nonuniform distribution of the intracellular signaling machinery $(\mathrm{Ng}$ and McAinsh, 2003). Regardless of the reason, the kinetics of $\left[\mathrm{Ca}^{2+}\right]_{\text {cyt }}$ reported in the literature reflect a result of integration of these non-uniform $\left[\mathrm{Ca}^{2+}\right]_{\mathrm{cyt}}$ domains within the cell. Moreover, quite often the measured signal reflects the integrated response of many cells and, thus, may combine responses from several populations of cell types (e.g., epidermal and cortical cells in plant roots). It is logical to expect that these cells may have rather different activities of $\mathrm{Ca}^{2+}$ pumps and exchangers and, as a result, display different $\left[\mathrm{Ca}^{2+}\right]_{\text {cyt }}$ kinetics in response to the same stimulus. As a result, the overall measured $\left[\mathrm{Ca}^{2+}\right]_{\text {cyt }}$ signal may be quite different from the response of each individual cell. This is further illustrated in Figure 6, which depicts $\left[\mathrm{Ca}^{2+}\right]_{\text {cyt }}$ kinetics from a population of $n=100$ cells having a normal (Gaussian) distribution of parameters $B$ and $D$.

Unsurprisingly, both lowering of the amplitude and broadening of the oscillations are observed. Moreover, the phase coherence between cells degrades with time, resulting in oscillations becoming more and more "smeared out." This is qualitatively consistent with results from the literature.

\section{Fitting experimental data}

As a final illustration of our model, we consider experimental data reporting changes in $\left[\mathrm{Ca}^{2+}\right]_{\mathrm{cyt}}$ in response to cold, osmotic stress, touch, and $\mathrm{H}_{2} \mathrm{O}_{2}$ in Arabidopsis seedlings, as per Logan and Knight (2003). In brief, changes in $\left[\mathrm{Ca}^{2+}\right]_{\text {cyt }}$ were observed in planta using recombinant aequorin Arabidopsis plants. Cold, mannitol, or $\mathrm{H}_{2} \mathrm{O}_{2}$ treatments were effected by slowly (to prevent a touch response) injecting $0.5 \mathrm{~mL}$ of ice-cold water, $0.7 \mathrm{M}$ mannitol, or $20 \mathrm{mM} \mathrm{H}_{2} \mathrm{O}_{2}$, respectively, into a cuvette containing an Arabidopsis seedling floating in $0.5 \mathrm{~mL}$ of water at room temperature. Touch treatment was effected by the rapid injection of $0.5 \mathrm{~mL}$ of room temperature water into the cuvette. The original data reported in that paper was digitized and is shown in respective panels in Figure 7.

As one can see, experimental data (unconnected symbols) can be adequately approximated by the model fits (continuous lines; Figure 7; also summarized in Table 1). Importantly, this is achieved by using a realistic (i.e., physiologically relevant) set of initial characteristics (see above), validating the adequacy of the model. Even more importantly, it appears that specific $\left[\mathrm{Ca}^{2+}\right]_{\text {cyt }}$ signatures observed in response to four different types of stress (cold, osmotic stress, touch, and $\mathrm{H}_{2} \mathrm{O}_{2}$ treatments) can be adequately achieved by modifying just the distributions of parameters $B$ and $D$, i.e., properties of $\mathrm{PM}$-based $\mathrm{Ca}^{2+}$ ATPase pump and endomembrane-based $\mathrm{Ca}^{2+} / \mathrm{H}^{+}$exchanger, respectively.

As such, we use the best fit to touch stress as the reference model. The difference between plant responses to cold and touch may be explained by a 1.5-fold increase in parameter $D$, a similar decrease in $B$, and a broadening of their distributions (compared to single-cell responses) by 23 and $6 \%$ of the mean, respectively. Much slower rise in $\left[\mathrm{Ca}^{2+}\right]_{\text {cyt }}$ in response to osmotic stress may be explained by still lower values of $B$ (with only a minimal change in $D$ ), while both sustained elevation and reduced peak 


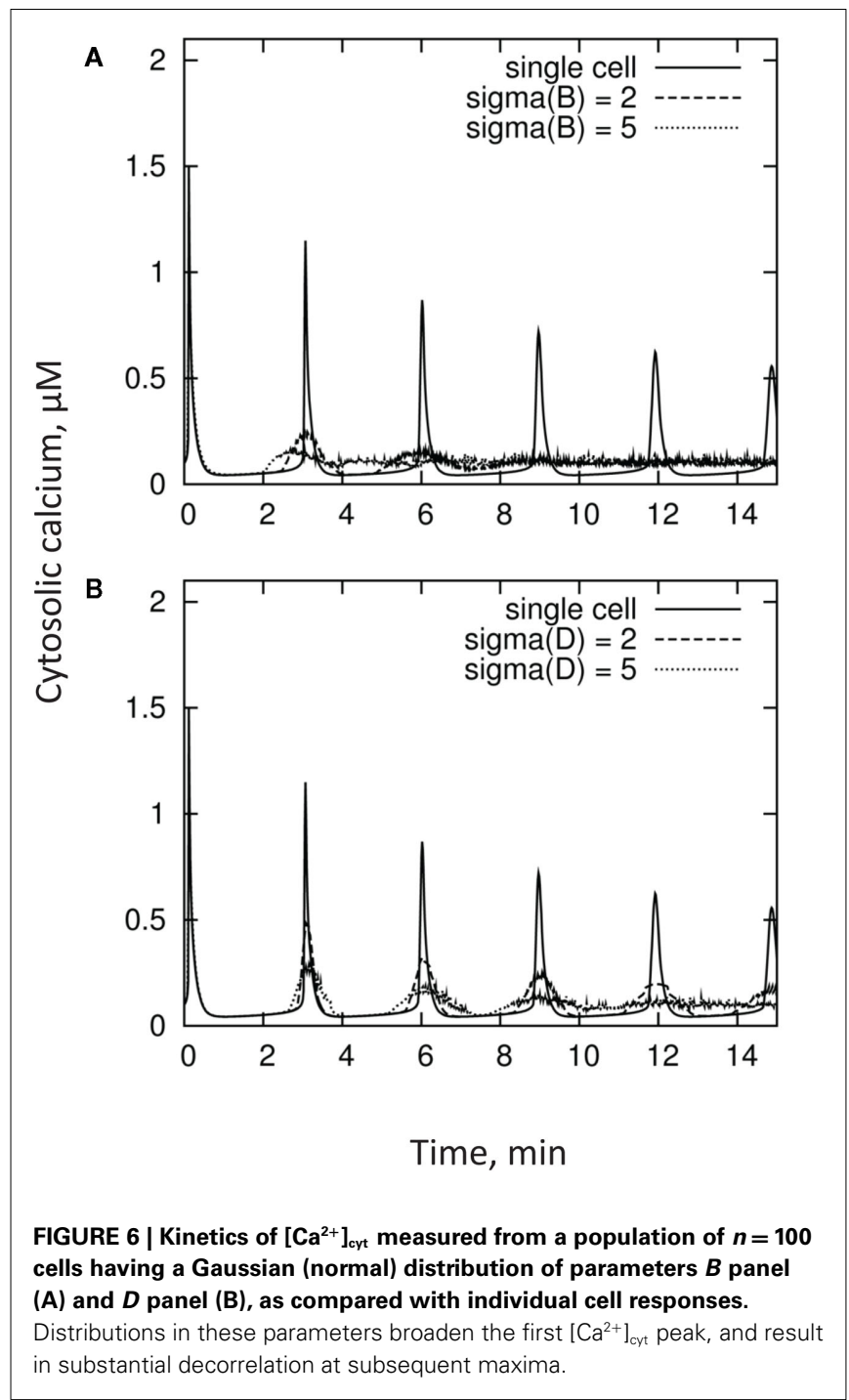

$\left[\mathrm{Ca}^{2+}\right]_{\text {cyt }}$ values in response to $\mathrm{H}_{2} \mathrm{O}_{2}$ treatment are given by a further decrease in $B$ and (slightly) higher $D$ values.

The dynamic range spanned by $D$ in these models is only 0.3 dex (i.e., a factor of 2); and the width of the normal distribution relative to the mean is $\sigma_{D} / D=0-0.07$. The dynamic range for $B$ is $0.9 \mathrm{dex}$ (factor of 8 ), and $\sigma_{D} / D=0-0.65$. Both these changes are within the physiological range of changes expected under stress conditions. Indeed, the efficiency of ATP production drops 19-fold (from 38 to only two ATP molecules; Gibbs and Greenway, 2003) under anoxic conditions; this is twice as wide as the dynamic range for $B$ in the models. Importantly, oxygen profiles in the root differ dramatically between epidermal, cortical, and stellar tissues (Armstrong et al., 1994), even under

\section{REFERENCES}

Allbritton, N. L., Meyer, T., and Stryer,

L. (1992). Range of messenger action of calcium ion and inositol 1, 4, 5-trisphosphate. Science 258, 1812-1815.
An, Z., Jing, W., Liu, Y., and Zhang, W. (2008). Hydrogen peroxide generated by copper amine oxidase is involved in abscisic acid-induced stomatal closure in Vicia faba. J. Exp. Bot. 59, 815-825.

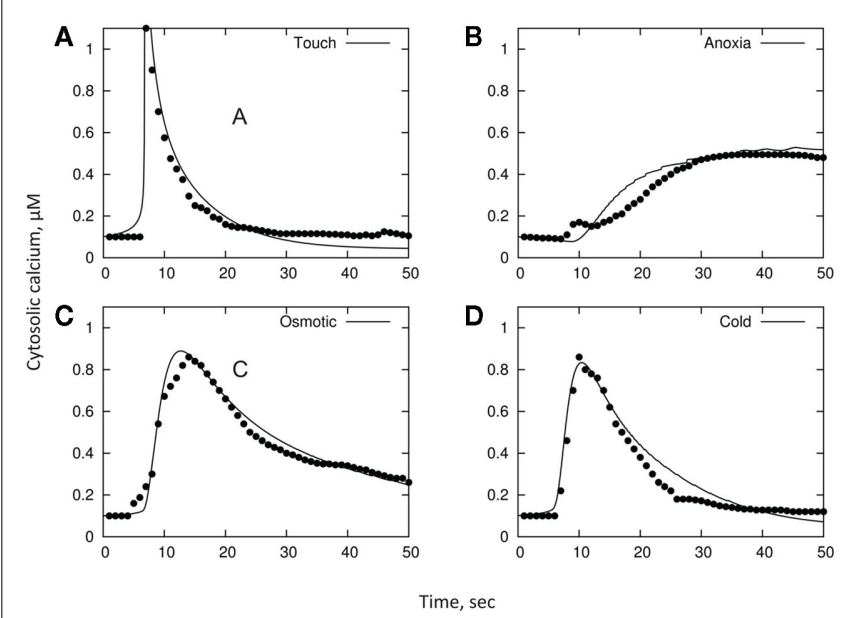

FIGURE 7 | A qualitative comparison between stress-induced $\left[\mathrm{Ca}^{2+}\right]_{\mathrm{cyt}}$ signatures and model simulation. Unconnected symbols are

experimental observations (as per Logan and Knight, 2003); lines are model fits. The basic parameters in all models are: $A=2 ; C=60 ; R=0.05$;

$B_{\max }=250 ; K_{\mathrm{d}}=0.6 ; y(t=0)=0.1 ; x(t=0)=160$. Only distributions in $B$ and $D$ are varied between treatments. The remaining parameters are: for cold panel (D), $B=13, \sigma_{B}=3, D=50, \sigma_{D}=3$; for osmotic panel (C), $B=8$, $\sigma_{B}=1, D=58, \sigma_{D}=4$; for touch panel (A), $B=20, \sigma_{B}=0.1, D=36, \sigma_{D}=0.1$; for $\mathrm{H}_{2} \mathrm{O}_{2}$ panel (B), $B=2.5, \sigma_{B}=1.7, D=74, \sigma_{D}=5$.

normoxic conditions. Thus, differential $\mathrm{Ca}^{2+}$-ATPase activity is expected between these tissues. This special heterogeneity will confer a broad dynamic range for $B$ and may explain the presence of the second peak in $\left[\mathrm{Ca}^{2+}\right]_{\text {cyt }}$ observed $30-40 \mathrm{~min}$ after anoxia onset (Figure 1C).

\section{CONCLUSION AND PROSPECTS}

Restoration of the basal $\left[\mathrm{Ca}^{2+}\right]_{\mathrm{cyt}}$ levels is essential for removing excess $\mathrm{Ca}^{2+}$ from the cytosol, to reload $\mathrm{Ca}^{2+}$ stores and to terminate $\mathrm{Ca}^{2+}$ signaling. (As shown in this paper, it is impossible to achieve this without having efficient $\mathrm{Ca}^{2+}$ efflux mechanisms in place). It also appears that physiologically relevant variations in the activity of $\mathrm{Ca}^{2+}$-ATPase pumps and $\mathrm{Ca}^{2+} / \mathrm{H}^{+}$exchangers are sufficient to fully describe all the reported experimental evidence and determine the shape of $\left[\mathrm{Ca}^{2+}\right]_{\mathrm{cyt}}$ signatures in response to environmental stimuli. This emphases the crucial role these active efflux systems play in plant adaptive responses to environment and suggests that more attention has to be given to elucidation of the spatio-temporal properties and control modes of $\mathrm{Ca}^{2+}$-ATPase pumps and $\mathrm{Ca}^{2+} / \mathrm{H}^{+}$exchangers in plants.

\section{ACKNOWLEDGMENTS}

This work was supported by the ARC Discovery grant DP1094663 and GRDC grant UT0022 to Sergey Shabala and CONACyT grant 82913 to Igor Pottosin.

Anil, V. S., Rajkumar, P., Kumar, P., and Mathew, M. (2008). A plant $\mathrm{Ca}^{2+}$ pump, ACA2, relieves salt hypersensitivity in yeast. J. Biol. Chem. 283, 3497-3506.
Arasimowicz-Jelonek, M., FloryszakWieczorek, J., and Kubi, J. (2009). Interaction between polyamine and nitric oxide signaling in adaptive responses to drought in cucumber. J. Plant Growth Regul. 28, 177-186. 
Armstrong, W., Strange, M. E., Cringle, S., and Beckett, P. M. (1994). Microelectrode and modeling study of oxygen distribution in roots. Ann. Bot. 74, 287-299.

Atkinson, M. M., Keppler, L. D., Orlandi, E. W., Baker, C. J., and Mischke, C. F. (1990). Involvement of plasma membrane calcium influx in bacterial induction of the $\mathrm{K}^{+} / \mathrm{H}^{+}$and hypersensitive responses in tobacco. Plant Physiol. 92, 215-221.

Axelsen, K., Venema, K., Jahn, T., Baunsgaard, L., and Palmgren, M. (1999). Molecular dissection of the C-terminal regulatory domain of the plant plasma membrane $\mathrm{H}^{+}$ATPase AHA2: mapping of residues that when altered give rise to an activated enzyme. Biochemistry 38, 7227-7234.

Balagué, C., Lin, B., Alcon, C., Flottes, G., Malmström, S., Köhler, C., Neuhaus, G., Pelletier, G., Gaymard, F., and Roby, D. (2003). HLM1, an essential signaling component in the hypersensitive response, is a member of the cyclic nucleotide-gated channel ion channel family. Plant Cell 15, 365-379.

Balijepalli, R. C., and Kamp, T. J. (2008). Caveolae, ion channels and cardiac arrhythmias. Prog. Biophys. Mol. Biol. 98, 149-160.

Bauer, C. S., Plieth, C., Bethmann, B., Popescu, O., Hansen, U.-P., Simonis, W., and Schonknecht, G. (1998). Strontium-induced repetitive calcium spikes in a unicellular green alga. Plant Physiol. 117, 545-557.

Beffagna, N., Buffoli, B., and Busi, C. (2005). Modulation of reactive oxygen species production during osmotic stress in Arabidopsis thaliana cultured cells: involvement of the plasma membrane $\mathrm{Ca}^{2+}$ ATPase and $\mathrm{H}^{+}$-ATPase. Plant Cell Physiol. 46, 1326-1339.

Berridge, M. J. (1997). The AM and FM of calcium signalling. Nature 386, 759-760.

Blatt, M. R. (1999). Reassessing roles for $\mathrm{Ca}^{2+}$ in guard cell signalling. J. Exp. Bot. 50, 989-999.

Blume, B., Nürnberger, T., Nass, N., and Scheel, D. (2000). Receptormediated increase in cytoplasmic free calcium required for activation of pathogen defense in parsley. Plant Cell 12, 1425-1440.

Blumwald, E., Aharon, G. S., and Lam, C. H. (1998). Early signal transduction pathways in plant-pathogen interactions. Trends Plant Sci. 3, 342-346.

Bonza, M. C., and De Michelis, M. (2011). The plant $\mathrm{Ca}^{2+}$ ATPase repertoire: biochemical features and physiological functions. Plant Biol. 13, 421-430.

Bonza, M. C., Morandini, P., Luoni, L., Geisler, M., Palmgren, M. G., and De Michelis, M. I. (2000). AtACA8 encodes a plasma membranelocalized calcium-ATPase of Arabidopsis with a calmodulin-binding domain at the $\mathrm{N}$ terminus. Plant Physiol. 123, 1495-1506.

Boursiac, Y., and Harper, J. F. (2007). The origin and function of calmodulin regulated $\mathrm{Ca}^{2+}$ pumps in plants. J. Bioenerg. Biomembr. 39, 409-414.

Brini, M., and Carafoli, E. (2009). Calcium pumps in health and disease. Physiol. Rev. 89, 1341-1378.

Baekgaard, L., Luoni, L., De Michelis, M. I., and Palmgren, M. G. (2006). The plant plasma membrane $\mathrm{Ca}^{2+}$ pump ACA8 contains overlapping as well as physically separated autoinhibitory and calmodulin-binding domains. $J$. Biol. Chem. 281, 1058-1065.

Baekgaard, L., Mikkelsen, M. D., Sørensen, D. M., Hegelund, J. N., Persson, D. P., Mills, R. F., Yang, Z., Husted, S., Andersen, J. P., and Buch-Pedersen, M. J. (2010). A combined zinc/cadmium sensor and zinc/cadmium export regulator in a heavy metal pump. J. Biol. Chem. 285, 31243-31252.

Cárdenas, L., Martínez, A., Sánchez, F. and Quinto, C. (2008). Fast, transient and specific intracellular ROS changes in living root hair cells responding to Nod factors (NFs). Plant J. 56, 802-813.

Case, R. M., Eisner, D., Gurney, A., Jones, O., Muallem, S., and Verkhratsky, A. (2007). Evolution of calcium homeostasis: from birth of the first cell to an omnipresent signalling system. Cell Calcium 42, 345-350.

Catalá, R., Santos, E., Alonso, J. M., Ecker, J. R., Martínez-Zapater, J. M., and Salinas, J. (2003). Mutations in the $\mathrm{Ca}^{2+} /{ }^{+}$Htransporter CAX1 increase CBF/DREB1 expression and the cold-acclimation response in Arabidopsis. Plant Cell 15, 2940-2951.

Cheng, N. H., and Hirschi, K. D. (2003). Cloning and characterization of CXIP1, a novel PICOT domain-containing Arabidopsis protein that associates with CAX1. J. Biol. Chem. 278, 6503-6509.

Cheng, N. H., Liu, J. Z., Nelson, R. S., and Hirschi, K. D. (2004a). Characterization of CXIP4, a novel Arabidopsis protein that activates the $\mathrm{H}^{+} / \mathrm{Ca}^{2+}$ antiporter, CAX1. FEBS Lett. 559, 99-106.

Cheng, N. H., Pittman, J. K., Zhu, J. K., and Hirschi, K. D. (2004b). The protein kinase SOS2 activates the Arabidopsis $\mathrm{H}^{+} / \mathrm{Ca}^{2+}$ antiporter CAX1 to integrate calcium transport and salt tolerance. J. Biol. Chem. 279, 2922-2926.

Cheng, N. H., Pittman, J. K., Barkla B. J., Shigaki, T., and Hirschi, K. D. (2003). The Arabidopsis caxl mutant exhibits impaired ion homeostasis, development, and hormonal responses and reveals interplay among vacuolar transporters. Plant Cell 15, 347-364.

Cheng, N. H., Pittman, J. K., Shigaki, T., and Hirschi, K. D. (2002a). Characterization of CAX4, an Arabidopsis $\mathrm{H}^{+} /$cation antiporter. Plant Physiol. 128, 1245-1254.

Cheng, S. H., Willmann, M. R., Chen, H. C., and Sheen, J. (2002b). Calcium signaling through protein kinases. The Arabidopsis calcium-dependent protein kinase gene family. Plant Physiol. 129, 469-485.

Cheng, N. H., Pittman, J. K., Shigaki, T., Lachmansingh, J., LeClere, S., Lahner, B., Salt, D. E., and Hirschi, K. D. (2005). Functional association of Arabidopsis CAX1 and CAX3 is required for normal growth and ion homeostasis. Plant Physiol. 138, 2048-2060.

Clayton, H., Knight, M. R., Knight, H., McAinsh, M. R., and Hetherington, A. M. (1999). Dissection of the ozone induced calcium signature. Plant J. 17, 575-579.

De Koninck, P., and Schulman, $\mathrm{H}$. (1998). Sensitivity of CaM kinase II to the frequency of $\mathrm{Ca}^{2+}$ oscillations. Science 279, 227-230.

DeFalco, T., Bender, K., and Snedden, W. (2010). Breaking the code: $\mathrm{Ca}^{2+}$ sensors in plant signalling. Biochem. J. 425, 27-40.

Demidchik, V., Bowen, H. C., Maathuis, F. J. M., Shabala, S. N., Tester, M. A., White, P. J., and Davies, J. M. (2002). Arabidopsis thaliana root non-selective cation channels mediate calcium uptake and are involved in growth. Plant J. 32, 799-808.

Demidchik, V., Shabala, S. N., Coutts, K. B., Tester, M. A., and Davies, J. M. (2003). Free oxygen radicals regulate plasma membrane $\mathrm{Ca}^{2+}$ and $\mathrm{K}^{+}$-permeable channels in plant root cells. J. Cell Sci. 116, 81-88.

Demidchik, V., Shabala, S. N., and Davies, J. M. (2007). Spatial variation in $\mathrm{H} 2 \mathrm{O} 2$ response of Arabidopsis thaliana root epidermal $\mathrm{Ca}^{2+}$ flux and plasma membrane $\mathrm{Ca}^{2+}$ channels. Plant J. 49, 377-386.

Dobrovinskaya, O. R., Muniz, J., and Pottosin, II. (1999). Inhibition of vacuolar ion channels by polyamines. J. Membr. Biol. 167, 127-140.

Dodd, A. N., Kudla, J., and Sanders, D. (2010). The language of calcium signaling. Annu. Rev. Plant Biol. 61, 593-620.

Dolmetsch, R. E., Lewis, R. S., Goodnow, C. C., and Healy, J. I. (1997). Differential activation of transcription factors induced by $\mathrm{Ca}^{2+}$ response amplitude and duration. Nature 386 855-858.

Dolmetsch, R. E., Xu, K., and Lewis, R. S. (1998). Calcium oscillations increase the efficiency and specificity of gene expression. Nature 392, 933-936.

Dutta, R., and Robinson, K. R. (2004). Identification and characterization of stretch-activated ion channels in pollen protoplasts. Plant Physiol. 135, 1398-1406.

Ehrhardt, D. W., Wais, R., and Long, S. R. (1996). Calcium spiking in plant root hairs responding to rhizobium nodulation signals. Cell 85 , 673-681.

Ettinger, W., Clear, A., Fanning, K. and Peck, M. (1999). Identification of a $\mathrm{Ca}^{2+} / \mathrm{H}^{+}$antiport in the plant chloroplast thylakoid membrane. Plant Physiol. 119, 1379-1385.

Feijo, J. A., Sainhas, J., Holdaway-Clarke, T., Cordeiro, M. S., Kunkel, J. G., and Hepler, P. K. (2001). Cellular oscillations and the regulation of growth: the pollen tube paradigm. Bioessays 23, 86-94.

Foreman, J., Demidchik, V., Bothwell, J. H. F., Mylona, P., Miedema, H., Torres, M. A., Linstead, P., Costa, S. Brownlee, C., Jones, J. D. G., Davies, J. M., and Dolan, L. (2003). Reactive oxygen species produced by NADPH oxidase regulate plant cell growth. Nature 422, 442-446.

Franzini-Armstrong, C., and Protasi, F. (1997). Ryanodine receptors of striated muscles: a complex channel capable of multiple interactions. Physiol. Rev. 77, 699-729.

Frietsch, S., Wang, Y. F., Sladek, C., Poulsen, L. R., Romanowsky, S. M., Schroeder, J. I., and Harper, J. F. (2007). A cyclic nucleotide-gated channel is essential for polarized tip growth of pollen. Proc. Natl. Acad. Sci. U.S.A. 104, 14531-14536.

Garufi, A., Visconti, S., Camoni, L., and Aducci, P. (2007). Polyamines as physiological regulators of 14-33 interaction with the plant plasma membrane $\mathrm{H}^{+}$-ATPase. Plant Cell Physiol. 48, 434-440.

Geisler, M., Frangne, N., Gomès, E., Martinoia, E., and Palmgren, M. G. (2000). The ACA4 gene of Arabidopsis encodes a vacuolar membrane calcium pump that improves salt tolerance in yeast. Plant Physiol. 124, 1814-1827. 
George, L., Romanowsky, S. M., Harper, J. F., and Sharrock, R. A. (2008). The ACA10 $\mathrm{Ca}^{2+}$-ATPase regulates adult vegetative development and inflorescence architecture in Arabidopsis. Plant Physiol. 146, 716-728.

Gibbs, J., and Greenway, H. (2003). Review: mechanisms of anoxia tolerance in plants. I. Growth, survival and anaerobic catabolism. Funct. Plant Biol. 30, 353-353.

Gifford, J., Walsh, M., and Vogel, H. (2007). Structures and metalion-binding properties of the $\mathrm{Ca}^{2+}$-binding helix-loop-helix EF-hand motifs. Biochem. J. 405, 199-221.

Gilroy, S., Fricker, M. D., Read, N. D., and Trewavas, A. J. (1991). Role of calcium in signal transduction of Commelina guard cells. Plant Cell 3 , 333-344.

Goddard, H., Manison, N., Tomos, D., and Brownlee, C. (2000). Elemental propagation of calcium signals in response-specific patterns determined by environmental stimulus strength. Proc. Natl. Acad. Sci. U.S.A. 97, 1932-1937.

Gong, M., van der Luit, A. H., Knight, M. R., and Trewavas, A. J. (1998). Heatshock-induced changes in intracellular $\mathrm{Ca}^{2+}$ level in tobacco seedlings in relation to thermotolerance. Plant Physiol. 116, 429-437.

Grabov, A., and Blatt, M. R. (1998). Coordination of signalling elements in guard cell ion channel control. J. Exp. Bot. 49, 351-360.

Grant, M., Brown, I., Adams, S., Knight, M., Ainslie, A., and Mansfield, J. (2000). The RPM1 plant disease resistance gene facilitates a rapid and sustained increase in cytosolic calcium that is necessary for the oxidative burst and hypersensitive cell death. Plant J. 23, 441-450.

Hajnoczky, G., Robb-Gaspers, L. D., Seitz, M., and Thomas, A. P. (1995). Decoding of cytosolic calcium oscillations in the mitochondria. Cell 82, 415-424.

Hann, D. R., and Rathjen, J. P. (2007). Early events in the pathogenicity of Pseudomonas syringae on Nicotiana benthamiana. Plant J. 49, 607-618.

Hansen, U.-P. (1978). Do light-induced changes in the membrane potential of Nitella reflect the feed-back regulation of a cytoplasmic parameter? J. Membr. Biol. 41, 197-224.

Harper, J. F. (2001). Dissecting calcium oscillators in plant cells. Trends Plant Sci. 6, 395-397.
Harper, J. F., Hong, B., Hwang, I., Guo, H. Q., Stoddard, R., Huang, J. F., Palmgren, M. G., and Sze, H. (1998). A novel calmodulin-regulated $\mathrm{Ca}^{2+}$ ATPase $\left(\mathrm{A} \mathrm{Ca}^{2}\right)$ from Arabidopsis with an $\mathrm{N}$-terminal autoinhibitory domain. J. Biol. Chem. 273, 1099-1106.

Heidelberger, R. (1998). Adenosine triphosphate and the late steps in calcium-dependent exocytosis at a ribbon synapse. J. Gen. Physiol. 111, 225-241.

Heidelberger, R., Heinemann, C., Neher, E., and Matthews, G. (1994). Calcium dependence of the rate of exocytosis in a synaptic terminal. Nature 371, 513-515.

Hepler, P. K., and Winship, L. J. (2010). Calcium at the cell wall cytoplast interface. J. Integr. Plant Biol. 52, 147-160.

Hille, B. (2001). Ionic Channels of Excitable Membranes. Sunderland, MA: Sinauer Associates.

Hirschi, K. (2001). Vacuolar $\mathrm{H}^{+} / \mathrm{Ca}^{2+}$ transport: who's directing the traffic? Trends Plant Sci. 6, 100-104.

Hirschi, K. D. (1999). Expression of Arabidopsis CAX1 in tobacco: altered calcium homeostasis and increased stress sensitivity. Plant Cell 11, 2113-2122.

Hirschi, K. D., Korenkov, V. D., Wilganowski, N. L., and Wagner, G. J. (2000). Expression of Arabidopsis CAX2 in tobacco. Altered metal accumulation and increased manganese tolerance. Plant Physiol. 124, 125-133.

Holdaway-Clarke, T. L., Feijo, J. A., Hacket, G. R., Kunkel, J. G., and Hepler, P. K. (1997). Pollen tube growth and the intracellular cytosolic calcium gradient oscillate in phase while extracellular calcium influx is delayed. Plant Cell 9, 1999-2010.

Homann, U., Meckel, T., Hewing, J., Hütt, M. T., and Hurst, A. C. (2007). Distinct fluorescent pattern of KAT1: GFP in the plasma membrane of Vicia faba guard cells. Eur. J. Cell Biol. 86, 489-500.

Huang, L., Berkelman, T., Franklin, A. E., and Hoffman, N. E. (1993). Characterization of a gene encoding a $\mathrm{Ca}^{2+}$-ATPase-like protein in the plastid envelope. Proc. Natl. Acad. Sci. U.S.A. 90, 10066-10070.

Ide, Y., Tomioka, R., Ouchi, Y., Kamiya, T., and Maeshima, M. (2007). Transcriptional induction of two genes for CCaPs, novel cytosolic proteins, in Arabidopsis thaliana in the dark. Plant Cell Physiol. 48, 54-65.

Ishida, H., and Vogel, H. J. (2010). The solution structure of a plant calmodulin and the CaM-binding domain of the vacuolar calciumATPase BCA1 reveals a new binding and activation mechanism. J. Biol. Chem. 285, 38502-38510.

Izu, L. T., and Spangler, R. A. (1993). Mathematical-analysis of a model for calcium oscillations based on calcium-induced calcium release and diffusion. FASEB J. 7, A239A239.

Jabs, T., Tschope, M., Colling, C., Hahlbrock, K., and Scheel, D. (1997) Elicitor-stimulated ion fluxes and $\mathrm{O}^{2-}$ from the oxidative burst are essential components in triggering defense gene activation and phytoalexin synthesis in parsley. Proc. Natl. Acad. Sci. U.S.A. 94 4800-4805.

James, P., Maeda, M., Fischer, R., Verma, A., Krebs, J., Penniston, J., and Carafoli, E. (1988). Identification and primary structure of a calmodulin binding domain of the $\mathrm{Ca}^{2+}$ pump of human erythrocytes. J. Biol. Chem. 263, 2905-2910.

Jornot, L., Maechler, P., Wollheim, C. B., and Junod, A. F. (1999). Reactive oxygen metabolites increase mitochondrial calcium in endothelial cells: implication of the $\mathrm{Ca}^{2+} / \mathrm{Na}^{+}$exchanger. J. Cell Sci. 112 1013-1022.

Kasai, M., and Muto, S. (1990). $\mathrm{Ca}^{2+}$ pump and $\mathrm{Ca}^{2+} / \mathrm{H}^{+}$antiporter in plasma membrane vesicles isolated by aqueous two-phase partitioning from corn leaves. J. Membr. Biol. 114 133-142.

Kiegle, E., Moore, C. A., Haseloff, J., Tester, M. A., and Knight, M. R (2000). Cell-type-specific calcium responses to drought, salt and cold in the Arabidopsis root. Plant J. 23 , 267-278.

Knight, M. R., Campbell, A. K., Smith, S. M., and Trewavas, A. J. (1991). Transgenic plant aequorin reports the effects of touch and cold-shock and elicitors on cytoplasmic calcium. Nature 352, 524-526.

Knight, M. R., Smith, S. M., and Trewavas, A. J. (1992). Wind-induced plant motion immediately increases cytosolic calcium. Proc. Natl. Acad. Sci. U.S.A. 89, 4967-4971.

Koopman, W., Scheenen, W., Schoolderman, L., Cruijsen, P., Roubos, E., and Jenks, B. (2001). Intracellular calcium buffering shapes calcium oscillations in Xenopus melanotropes. Pflugers Arch. 443, 250-256.

Kudla, J., Batisti, O., and Hashimoto, K. (2010). Calcium signals: the lead currency of plant information processing. Plant Cell 22, 541-563.
Kukavica, B., Mojovi, M., Vuc ini, Ž., Maksimovi, V., Takahama, U. and Jovanovi, S. V. (2009). Generation of hydroxyl radical in isolated pea root cell wall, and the role of cell wall-bound peroxidase, $\mathrm{Mn}-\mathrm{SOD}$ and phenolics in their production. Plant Cell Physiol. 50, 304-317.

Kuratomi, S., Matsuoka, S., Sarai, N., Powell, T., and Noma, A. (2003). Involvement of $\mathrm{Ca}^{2+}$ buffering and $\mathrm{Na}^{+} / \mathrm{Ca}^{2+}$ exchange in the positive staircase of contraction in guineapig ventricular myocytes. Pflugers Arch. 446, 347-355.

Lam, E., Kato, N., and Lawton, M. (2001). Programmed cell death, mitochondria and the plant hypersensitive response. Nature 411, 848-853.

Leckie, C. P., McAinsh, M. R., Montgomery, L., Priestley, A. J., Staxen, I., Webb, A. A. R., and Hetherington, A. M. (1998). Second messengers in guard cells. J. Exp. Bot. 49, 339-349.

Lecourieux, D., Mazars, C., Pauly, N., Ranjeva, R., and Pugin, A. (2002). Analysis and effects of cytosolic free calcium increases in response to elicitors in Nicotiana plumbaginifolia cells. Plant Cell 14, 2627-2641.

Lee, S. M., Kim, H. S., Han, H. J., Moon, B. C., Kim, C. Y., Harper, J. F., and Chung, W. S. (2007). Identification of a calmodulin-regulated autoinhibited $\mathrm{Ca}^{2+}$-ATPase (ACA11) that is localized to vacuole membranes in Arabidopsis. FEBS Lett. 581, 3943-3949.

Levine, A., Pennell, R. I., Alvarez, M. E., and Palmer, R. (1996). Calciummediated apoptosis in a plant hypersensitive disease resistance response. Curr. Biol. 6, 427-437.

Lew, P. D., Wollheim, C. B., Waldvogel, F. A., and Pozzan, T. (1984) Modulation of cytosolic-free calcium transients by changes in intracellular calcium-buffering capacity: correlation with exocytosis and $\mathrm{O} 2$ production in human neutrophils. $J$. Cell. Biol. 99, 1212-1220.

Li, W. H., Llopis, J., Whitney, M., Zlokarnik, G., and Tsien, R. Y. (1998). Cell-permeant caged InsP3 ester shows that $\mathrm{Ca}^{2+}$ spike frequency can optimize gene expression. Nature 392, 936-941.

Li, X., Chanroj, S., Wu, Z., Romanowsky, S. M., Harper, J. F., and Sze, H. (2008). A distinct endosomal $\mathrm{Ca}^{2+} / \mathrm{Mn}^{+}$pump affects root growth through the secretory process. Plant Physiol. 147, 1675-1689. 
Liang, F., Cunningham, K. W., Harper, J. F., and Sze, H. (1997). ECA1 complements yeast mutants defective in $\mathrm{Ca}^{2+}$ pumps and encodes an endoplasmic reticulum-type $\mathrm{Ca}^{2+}$. ATPase in Arabidopsis thaliana. Proc. Natl. Acad. Sci. U.S.A. 94, 8579-8584.

Lin, S., Fagan, K. A., Li, K. X., Shaul, P. W., Cooper, D. M. F., and Rodman, D. M. (2000). Sustained endothelial nitric-oxide synthase activation requires capacitative $\mathrm{Ca}^{2+}$ entry. J. Biol. Chem. 275, 17979-17985.

Liszkay, A., Van Der Zalm, E., and Schopfer, P. (2004). Production of reactive oxygen intermediates $\left(\mathrm{O}_{2}{ }^{-}\right.$, $\mathrm{H} 2 \mathrm{O} 2$, and $\mathrm{OH}$ ) by maize roots and their role in wall loosening and elongation growth. Plant Physiol. 136, 3114-3123.

Liu, K., Fu, H. H., Bei, Q. X., and Luan, S. (2000). Inward potassium channel in guard cells as a target for polyamine regulation of stomatal movements. Plant Physiol. 124, 1315-1325.

Liu, P., Li, R. L., Zhang, L., Wang, Q. L., Niehaus, K., Baluška, F., Šamaj, J., and Lin, J. X. (2009). Lipid microdomain polarization is required for NADPH oxidase dependent ROS signaling in Picea meyeri pollen tube tip growth. Plant J. 60, 303-313.

Llinas, R., Sugimori, M., and Silver, R. (1992). Microdomains of high calcium concentration in a presynaptic terminal. Science 256, 677-679.

Lloyd, D., and Stupfel, M. (1991). The occurrence and functions of ultradian rhythms. Biol. Rev. Camb. Philos. Soc. 66, 275-299.

Logan, D. C., and Knight, M. R. (2003). Mitochondrial and cytosolic calcium dynamics are differentially regulated in plants. Plant Physiol. 133, 21-24.

Luan, S., Kudla, J., RodriguezConcepcion, M., Yalovsky, S., and Gruissem, W. (2002). Calmodulins and calcineurin B-like proteins: calcium sensors for specific signal response coupling in plants. Plant Cell 14, 389-400.

Luo, G. Z., Wang, H. W., Huang, J., Tian, A. G., Wang, Y. J., Zhang, J. S., and Chen, S. Y. (2005). A putative plasma membrane cation/proton antiporter from soybean confers salt tolerance in Arabidopsis. Plant Mol. Biol. 59, 809-820.

Luoni, L., Meneghelli, S., Bonza, M. C., and DeMichelis, M. I. (2004). Autoinhibition of Arabidopsis thaliana plasma membrane $\mathrm{Ca}^{2+}$-ATPase involves an interaction of the $\mathrm{N}$ terminus with the small cytoplasmic loop. FEBS Lett. 574, 20-24.
Malmström, S., Askerlund, P., and Palmgren, M. G. (1997). A calmodulin-stimulated $\quad \mathrm{Ca}^{2+}$ ATPase from plant vacuolar membranes with a putative regulatory domain at its N-terminus. FEBS Lett. 400 324-328.

Manohar, M., Shigaki, T., and Hirschi, K. (2011). Plant cation $/ \mathrm{H}^{+}$exchangers (CAXs): biological functions and genetic manipulations. Plant Biol. 13, 561-569.

Martinez-Serrano, A., Blanco, P., and Satrustegui, J. (1992). Calciumbinding to the cytosol and calcium extrusion mechanisms in intact synaptosomes and their alterations with aging. J. Biol. Chem. 267, 4672-4679.

Mäser, P., Thomine, S., Schroeder, J. I., Ward, J. M., Hirschi, K., Sze, H., Talke, I. N., Amtmann, A., Maathuis, F. J. M., and Sanders, D. (2001). Phylogenetic relationships within cation transporter families of Arabidopsis. Plant Physiol. 126, 1646-1667.

May, R. (1989). The chaotic rhythms of life. New Sci. 21-25.

McAinsh, M. R., Brownlee, C., and Hetherington, A. M. (1997). Calcium ions as second messengers in guard cell signal transduction. Physiol. Plant 100, 16-29.

McAinsh, M. R., and Hetherington, A. M. (1998). Encoding specificity in $\mathrm{Ca}^{2+}$ signalling systems. Trends Plant Sci. 3, 32-36.

McAinsh, M. R., and Pittman, J. K. (2009). Shaping the calcium signature. New Phytol. 181, 275-294.

McAinsh, M. R., Webb, A. A. R., Taylor, J. E., and Hetherington, A. M. (1995). Stimulus-induced oscillations in guard cell cytosolic free calcium. Plant Cell 7, 1207-1219.

McCormack, E., Tsai, Y. C., and Braam, J. (2005). Handling calcium signaling: Arabidopsis CaMs and CMLs. Trends Plant Sci. 10, 383-389.

Medvedev, S. S. (2005). Calcium signaling system in plants. Russ. J. Plant Physiol. 52, 249-270.

Mei, H., Zhao, J., Pittman, J. K., Lachmansingh, J., Park, S., and Hirschi, K. D. (2007). In planta regulation of the Arabidopsis $\mathrm{Ca}^{2+} / \mathrm{H}^{+}$ antiporter CAX1. J. Exp. Bot. 58, 3419-3427.

Meksuriyen, D., Fukuchi-Shimogori, T., Tomitori, H., Kashiwagi, K., Toida, T., Imanari, T., Kawai, G., and Igarashi, K. (1998). Formation of a complex containing ATP, $\mathrm{Mg}^{+}$ and spermine. J. Biol. Chem. 273, 30939-30944.
Mills, R. F., Doherty, M. L., LópezMarqués, R. L., Weimar, T., Dupree, P., Palmgren, M. G., Pittman, J. K., and Williams, L. E. (2008). ECA3, a Golgi-localized P2A-type ATPase, plays a crucial role in manganese nutrition in Arabidopsis. Plant Physiol. 146, 116-128.

Miwa, H., Sun, J., Oldroyd, G. E. D., and Allan Downie, J. (2006). Analysis of calcium spiking using a cameleon calcium sensor reveals that nodulation gene expression is regulated by calcium spike number and the developmental status of the cell. Plant J. 48, 883-894.

Møller, J. V., Olesen, C., Winther, A. M. L., and Nissen, P. (2010). The sarcoplasmic $\mathrm{Ca}^{2+}$-ATPase: design of a perfect chemi-osmotic pump. Q. Rev. Biophys. 43, 501-566.

Mons, N., Decorte, L., Jaffard, R., and Cooper, D. (1998). $\mathrm{Ca}^{2+}$-sensitive adenylyl cyclases, key integrators of cellular signalling. Life Sci. 62, 1647-1652.

Monshausen, G. B., Messerli, M. A., and Gilroy, S. (2008). Imaging of the yellow cameleon 3.6 indicator reveals that elevations in cytosolic $\mathrm{Ca}^{2+}$ follow oscillating increases in growth in root hairs of Arabidopsis. Plant Physiol. 147, 1690-1698.

Moreno, I., Norambuena, L., Maturana, D., Toro, M., Vergara, C., Orellana, A., Zurita-Silva, A., and Ordenes, V. R. (2008). AtHMAl is a thapsigargin-sensitive $\mathrm{Ca}^{2+} /$ heavy metal pump. J. Biol. Chem. 283, 9633-9641.

Morth, J. P., Pedersen, B. P., BuchPedersen, M. J., Andersen, J. P., Vilsen, B., Palmgren, M. G., and Nissen, P. (2011). A structural overview of the plasma membrane $\mathrm{Na}^{+}, \mathrm{K}^{+}$-ATPase and $\mathrm{H}^{+}$-ATPase ion pumps. Nat. Rev. Mol. Cell Biol. 12, 60-70.

Moschou, P. N., Paschalidis, K. A., and Roubelakis-Angelakis, K. A. (2008). Plant polyamine catabolism: the state of the art. Plant Signal. Behav. 3, 1061-1066.

Naraghi, M., and Neher, E. (1997). Linearized buffered $\mathrm{Ca}^{2}$ (diffusion in microdomains and its implications for calculation of $\left[\mathrm{Ca}^{2+}\right]$ at the mouth of a calcium channel. J. Neurosci. 17, 6961-6973.

Nemchinov, L. G., Shabala, L., and Shabala, S. (2008). Calcium efflux as a component of the hypersensitive response of Nicotiana benthamiana to Pseudomonas syringae. Plant Cell Physiol. 49, 40-46.

Ng, C. K. Y., and McAinsh, M. R. (2003). Encoding specificity in plant calcium signalling: hot-spotting the ups and downs and waves. Ann. Bot. 92, 477-485.

Nurnberger, T., Nennsteil, D., Jabs, T., Sacks, W. R., Hahlbrock, K., and Scheel, D. (1994). High affinity binding of a fungal oligopeptide elicitor to parsley plasma membranes triggers multiple defense responses. Cell 78, 449-460.

Palmgren, M., and Nissen, P. (2011). Ptype ATPases. Annu. Rev. Biophys. 40, 243-266.

Pei, Z. M., Murata, Y., Benning, G., Thomine, S., Klusener, B., Allen, G. J., Grill, E., and Schroeder, J. I. (2000). Calcium channels activated by hydrogen peroxide mediate abscisic acid signalling in guard cells. Nature 406, 731-734.

Pérez, V., Wherrett, T., Shabala, S., Muniz, J., Dobrovinskaya, O., and Pottosin, I. (2008). Homeostatic control of slow vacuolar channels by luminal cations and evaluation of the channel-mediated tonoplast $\mathrm{Ca}^{2+}$ fluxes in situ. J. Exp. Bot. 59, 3845-3855.

Pike, S. M., Zhang, X. C., and Gassmann, W. (2005). Electrophysiological characterization of the Arabidopsis avrRpt2-specific hypersensitive response in the absence of other bacterial signals. Plant Physiol. 138, 1009-1017.

Pittman, J. K., and Hirschi, K. D. (2003). Don't shoot the (second) messenger: endomembrane transporters and binding proteins modulate cytosolic $\mathrm{Ca}^{2+}$ levels. Curr. Opin. Plant Biol. 6, 257-262.

Pittman, J. K., Shigaki, T., Cheng, N.-H., and Hirschi, K. D. (2002). Mechanism of N-terminal autoinhibition in the Arabidopsis $\mathrm{Ca}^{2+} / \mathrm{H}^{+}$ Antiporter CAX1. J. Biol. Chem. 277, 26452-26459.

Plieth, C., Sattelmacher, B., and Hansen, U.-P. (1997). Cytoplasmic $\mathrm{Ca}^{2+}-\mathrm{H}^{+}-$ exchange buffers in green algae. Protoplasma 198, 107-124.

Poburko, D., Kuo, K. H., Dai, J., Lee, C. H., and van Breemen, C. (2004) Organellar junctions promote targeted $\mathrm{Ca}^{2+}$ signaling in smooth muscle: why two membranes are better than one. Trends Pharmacol. Sci. 25, 8-15.

Pottosin, II, Tikhonova, L. I., Hedrich, R., and Schonknecht, G. (1997) Slowly activating vacuolar channels can not mediate $\mathrm{Ca}^{2+}$. induced $\mathrm{Ca}^{2+}$ release. Plant J. 12 , 1387-1398.

Price, A. H., Taylor, A., Ripley, S. J., Griffiths, A., Trewavas, A. J., and Knight, M. R. (1994). Oxidative signals in tobacco increase cytosolic calcium. Plant Cell 6, 1301-1310. 
Qudeimat,E., Faltusz, A. M.C., Wheeler, G., Lang, D., Brownlee, C., Reski, R., and Frank, W. (2008). A PIIB-type $\mathrm{Ca}^{2+}$-ATPase is essential for stress adaptation in Physcomitrella patens. Proc. Natl. Acad. Sci. U.S.A. 105, 19555-19560.

Rand, R. H., Upadhyaya, S. K., Cooke, J. R., and Storti, D. W. (1981). Hopf bifurcation in a stomatal oscillator. J. Math. Biol. 12, 1-11.

Ranf, S., Wunnenberg, P., Lee, J., Becker, D., Dunkel, M., Hedrich, R., Scheel, D., and Dietrich, P. (2008). Loss of the vacuolar cation channel, AtTPC1, does not impair $\mathrm{Ca}^{2+}$ signals induced by abiotic and biotic stresses. Plant J. 53, 287-299.

Rapp, P. E. (1987). Why are so many biological systems periodic? Prog. Neurobiol. 29, 261-273.

Rapp, P. E., Mees, A. I., and Sparrow, C. T. (1981). Frequency encoded biochemical regulation is more accurate than amplitude dependent control. J. Theor. Biol. 90, 531-544.

Rizzuto, R., and Pozzan, T. (2006). Microdomains of intracellular $\mathrm{Ca}^{2+}$ : molecular determinants and functional consequences. Physiol. Rev. 86, 369-408.

Roelfsema, M. R. G., and Hedrich, R. (2010). Making sense out of $\mathrm{Ca}^{2+}$ signals: their role in regulating stomatal movements. Plant Cell Environ. 33, 305-321.

Romani, G., Bonza, M. C., Filippini, I., Cerana, M., Beffagna, N., and De Michelis, M. I. (2004). Involvement of the plasma membrane $\mathrm{Ca}^{2+}$ ATPase in the short-term response of Arabidopsis thaliana cultured cells to oligogalacturonides. Plant Biol. 6, 192-200.

Sanders, D., Brownlee, C., and Harper, J. F. (1999). Communicating with calcium. Plant Cell 11, 691-706.

Schiøtt, M., and Palmgren, M. G. (2005). Two plant $\mathrm{Ca}^{2+}$ pumps expressed in stomatal guard cells show opposite expression patterns during cold stress. Physiol. Plant 124, 278-283.

Schiøtt, M., Romanowsky, S. M., Bækgaard, L., Jakobsen, M. K., Palmgren, M. G., and Harper, J. F. (2004). A plant plasma membrane $\mathrm{Ca}^{2+}$ pump is required for normal pollen tube growth and fertilization. Proc. Natl. Acad. Sci. U.S.A. 101, 9502-9507.

Schonknecht, G., Bauer, C. S., and Simonis, W. (1998). Light-dependent signal transduction and transient changes in cytosolic $\mathrm{Ca}^{2+}$ in a unicellular green alga. J. Exp. Bot. 49, $1-11$.

Schönknecht, G., and Bethmann, B. (1998). Cytosolic $\mathrm{Ca}^{2+}$ and $\mathrm{H}^{+}$ buffers in green algae: a comment. Protoplasma 203, 206-209.
Schulz-Lessdorf, B., and Hedrich, R. (1995). Protons and calcium modulate SV-type channels in the vacuolar- lysosomal compartment channel interaction with calmodulin inhibitors. Planta 197, 655-671.

Schwaller, B. (2009). The continuing disappearance of "pure" $\mathrm{Ca}^{2+}$ buffers. Cell. Mol. Life Sci. 66, 275-300.

Sedbrook, J. C., Kronebusch, P. J., Borisy, C. G., Trewavas, A. J., and Masson, P. H. (1996). Transgenic AEQUORIN reveals organ-specific cytosolic $\mathrm{Ca}^{2+}$ responses to anoxia in Arabidopsis thaliana seedlings. Plant Physiol. 111, 243-257.

Shabala, S., Bækgaard, L., Shabala, L., Fuglsang, A., Babourina, O., Palmgren, M. G., Cuin, T. A., Rengel, Z., and Nemchinov, L. G. (2011a). Plasma membrane $\mathrm{Ca}^{2+}$ transporters mediate virus induced acquired resistance to oxidative stress. Plant Cell Environ. 34, 406-417.

Shabala, S., Bækgaard, L., Shabala, L., Fuglsang, A. T., Cuin, T. A., Nemchinov, L. G., and Palmgren, M. G. (2011b). Endomembrane $\mathrm{Ca}^{2+}$ ATPases play a significant role in virus-induced adaptation to oxidative stress. Plant Signal. Behav. 6, 1053-1056.

Shabala, S., Cuin, T. A., and Pottosin, I. (2007). Polyamines prevent $\mathrm{NaCl}$-induced $\mathrm{K}^{+}$efflux from pea mesophyll by blocking non-selective cation channels. FEBS Lett. 581, 1993-1999.

Shabala, S., Delbourgo, R., and Newman, I. (1997). Observations of bifurcation and chaos in plant physiological responses to light. Aust. J. Plant Physiol. 24, 91-96.

Shabala, S., Shabala, L., Gradmann, D., Chen, Z. H., Newman, I., and Mancuso, S. (2006). Oscillations in plant membrane transport: model predictions, experimental validation, and physiological implications. J. Exp. Bot. 57, 171-184.

Shang, Z., Ma, L., Zhang, H., He, R., Wang, X., Cui, S., and Sun, D. (2005). $\mathrm{Ca}^{2+}$ influx into lily pollen grains through a hyperpolarizationactivated $\mathrm{Ca}^{2+}$-permeable channel which can be regulated by extracellular CaM. Plant Cell Physiol. 46, 598-608.

Shigaki, T., and Hirschi, K. (2006). Diverse functions and molecular properties emerging for CAX cation $/ \mathrm{H}^{+}$exchangers in plants. Plant Biol. 8, 419-429.

Shigaki, T., Mei, H., Marshall, J., Li, X., Manohar, M., and Hirschi, K. (2010). The expression of the open reading frame of Arabidopsis CAX1, but not its cDNA, confers metal tolerance in yeast. Plant Biol. 12, 935-939.

Shigaki, T., Rees, I., Nakhleh, L., and Hirschi, K. (2006). Identification of three distinct phylogenetic groups of CAX cation/proton antiporters. $J$. Mol. Evol. 63, 815-825.

Soldatov, N. M. (2003). $\mathrm{Ca}^{2+}$ channel moving tail: link between $\mathrm{Ca}^{2+}$. induced inactivation and $\mathrm{Ca}^{2+}$ signal transduction. Trends Pharmacol. Sci. 24, 167-171.

Spät, A., Fülöp, L., Koncz, P., and Szanda G. (2009). When is high $\mathrm{Ca}^{2+}$ microdomain required for mitochondrial $\mathrm{Ca}^{2+}$ uptake? Acta Physiol. (Oxf.) 195, 139-147.

Staxén, I., Pical, C., Montgomery, L. T. Gray, J. E., Hetherington, A. M., and McAinsh, M. R. (1999). Abscisic acid induces oscillations in guard-cell cytosolic free calcium that involve phosphoinositide-specific phospholipase C. Proc. Natl. Acad. Sci. U.S.A. 96, 1779-1784.

Stucki, J. W., and Somogyi, R. (1994). A dialog on $\mathrm{Ca}^{2+}$ oscillations: an attempt to understand the essentials of mechanisms leading to hormone-induced intracellular $\mathrm{Ca}^{2+}$ oscillations in various kinds of cell on a theoretica level. Biochim. Biophys. Acta 1183, 453-472.

Sutter, J. U., Campanoni, P., Tyrrell, M., and Blatt, M. R. (2006). Selective mobility and sensitivity to SNAREs is exhibited by the Arabidopsis KAT1 $\mathrm{K}^{+}$channel at the plasma membrane. Plant Cell 18 935-954.

Sze, H., Liang, F., Hwang, I., Curran, A. C., and Harper, J. F. (2000). Diversity and regulation of plant $\mathrm{Ca}^{2+}$ pumps: insights from expression in yeast. Annu. Rev. Plant Physiol. Plant Mol. Biol. 51, 433-462.

Takeda, S., Gapper, C., Kaya, H., Bell, E. Kuchitsu, K., and Dolan, L. (2008). Local positive feedback regulation determines cell shape in root hair cells. Science 319, 1241-1244.

Tang, Y., and Othmer, H. G. (1995). Frequency encoding in excitable systems with application to calcium oscillations. Proc. Natl. Acad. Sci. U.S.A. 92, 7869-7873.

Terada, L. S. (2006). Specificity in reactive oxidant signaling: think globally, act locally. J. Cell Biol. 174, 615-623.

Tracy, F. E., Gilliham, M., Dodd, A. N., Webb, A. A. R., and Tester, M. (2008). NaCl-induced changes in cytosolic free $\mathrm{Ca}^{2+}$ in Arabidopsis thaliana are heterogeneous and modified by external ionic composition. Plant Cell Environ. 31, 1063-1073.
Trewavas, A. (1999). Le calcium, c'est la vie: calcium makes waves. Plant Physiol. 120, 1-6.

Tun, N. N., Santa-Catarina, C., Begum, T., Silveira, V., Handro, W., Floh, E. I. S., and Scherer, G. F. E. (2006). Polyamines induce rapid biosynthesis of nitric oxide (NO) in Arabidopsis thaliana seedlings. Plant Cell Physiol. 47, 346-354.

Tuteja, N., and Mahajan, S. (2007). Calcium signaling network in plants: an overview. Plant Signal. Behav. 2, 79-85.

Ward, J. M., and Schroeder, J. I. (1994). Calcium-activated $\mathrm{K}^{+}$channels and calcium-induced calcium-release by slow vacuolar ion channels in guardcell vacuoles implicated in the control of stomatal closure. Plant Cell 6, 669-683.

Waring, P. (2005). Redox active calcium ion channels and cell death. Arch. Biochem. Biophys. 434, 33-42.

White, P. J., and Broadley, M. R. (2003). Calcium in plants. Ann. Bot. 92, 487-511.

Zaidi, A., and Michaelis, M. L. (1999). Effects of reactive oxygen species on brain synaptic plasma membrane $\mathrm{Ca}^{2+}$-ATPase. Free Radic. Biol. Med. 27, 810-821.

Zandonadi, D. B., Santos, M. P., Dobbss, L. B., Olivares, F. L., Canellas, L. P., Binzel, M. L., Okorokova-Façanha, A. L., and Façanha, A. R. (2010). Nitric oxide mediates humic acidsinduced root development and plasma membrane $\mathrm{H}^{+}$-ATPase activation. Planta 231, 1025-1036.

Zappel, N. F., and Panstruga, R. (2008) Heterogeneity and lateral compartmentalization of plant plasma membranes. Curr. Opin. Plant Biol. 11, 632-640.

Zhao, F., Song, C. P., He, J., and Zhu, H. (2007). Polyamines improve $\mathrm{K}^{+} / \mathrm{Na}^{+}$homeostasis in barley seedlings by regulating root ion channel activities. Plant Physiol. 145, 1061-1072.

Zhao, J., Barkla, B., Marshall, J., Pittman, J., and Hirschi, K. (2008). The Arabidopsis cax3 mutants display altered salt tolerance, $\mathrm{pH}$ sensitivity and reduced plasma membrane $\mathrm{H}^{+}$-ATPase activity. Planta 227, 659-669.

Zhao, J., Shigaki, T., Mei, H., Guo, Y., Cheng, N. H., and Hirschi, K. D. (2009). Interaction between Arabidopsis $\mathrm{Ca}^{2+} / \mathrm{H}^{+}$exchangers CAX1 and CAX3. J. Biol. Chem. 284, 4605-4615.

Zielinski, R. E. (1998). Calmodulin and calmodulin-binding proteins in plants. Annu. Rev. Plant Physiol. Plant Mol. Biol. 49, 697-725. 
Zweifach, A., and Lewis, R. S. (1995). Rapid inactivation of depletion-activated calcium current (ICRAC) due to local calcium feedback. J. Gen. Physiol. 105, 209-226.

Conflict of Interest Statement: The authors declare that the research was conducted in the absence of any commercial or financial relationships that could be construed as a potential conflict of interest.

Received: 15 August 2011; paper pending published: 15 September 2011; accepted: 04 November 2011; published online: 02 December 2011.
Citation: Bose J, Pottosin II, Shabala SS, Palmgren $M G$ and Shabala $S$ (2011) Calcium efflux systems in stress signaling and adaptation in plants. Front. Plant Sci. 2:85. doi: 10.3389/fpls.2011.00085

This article was submitted to Frontiers in Plant Biophysics and Modeling, a specialty of Frontiers in Plant Science.
Copyright (c) 2011 Bose, Pottosin, Shabala, Palmgren and Shabala. This is an open-access article subject to a nonexclusive license between the authors and Frontiers Media SA, which permits use, distribution and reproduction in other forums, provided the original authors and source are credited and other Frontiers conditions are complied with. 